

GEOCHRONOMETRIA 40(1) 2013: 59-76

DOI 10.2478/s13386-012-0021-5

Available online at

www.springerlink.com

\title{
META-ANALYSIS OF DENDROCHRONOLOGICAL DATING OF MASS MOVEMENTS
}

\author{
JAN TUMAJER and VÁCLAV TREML \\ Charles University in Prague, Faculty of Science, Department of Physical Geography and Geoecology, \\ Albertov 6, Prague, 12843
}

Received 12 January 2012

Accepted 21 September 2012

\begin{abstract}
Absolute dating of mass movements is crucial for disentangling possible release factors and determining the frequency of events. Here, we present an overview of a recent approach to dendrochronological dating of rockfalls, flows, landslides and avalanches. The results, based on 69 casestudies, show that methodological approaches to sampling and material processing differ considerably for different types of mass movements. Landslides are usually detected through abrupt growth changes and changes in stem eccentricity, whereas high-energy events as avalanches and flows are mostly identified by the formation of traumatic resin ducts, reaction wood, growth injuries and eccentricity changes. Cross-dating of dead wood is applicable as well. The dating of most mass movements except landslides is common, even with sub-annual resolution. In comparison to other methods of absolute dating, the main benefit of dendrochronology still lies in the high temporal resolution of the results. If living material is accessible, on-going research progress makes absolute dating of most mass-wasting events possible with sub-annual precision.
\end{abstract}

Keywords: dendrogeomorphology, disturbances, meta-analysis, mass-movement, absolute dating

\section{INTRODUCTION}

Slope movements are one example of natural processes that can pose a serious risk to human beings and their possessions (Kukal and Pošmourný, 2005). Data regarding former mass-movement events are very useful for producing reliable estimates of their frequency and spatial extent (Stoffel and Bollschweiler, 2009a). If there are written records or eye-witness accounts of former reactivations in a given location, they can be very easily used as a source of information. The problem is that memories of an individual are very subjective and underestimate events that may have (i) occurred in unpopulated areas and (ii) did not lead to material losses or injuries (Boll-

Corresponding author: V. Treml

e-mail: treml@natur.cuni.cz

ISSN 1897-1695 (online), 1733-8387 (print)

(C) 2012 Silesian University of Technology, Gliwice, Poland.

All rights reserved. schweiler et al., 2011). In comparison, the application of relative or absolute dating techniques provides more objective results (Lang et al., 1999). Dendrochronology represents an appropriate method for dating massmovements on decadal to millennial time scales. The fundamental principle of dendrochronological dating is the reconstruction of former events using tree rings and other anatomic structures of trees and shrubs growing in the affected area (Alestalo, 1971; Gärtner, 2007b; Stoffel and Bollschweiller, 2008). In particular, debris flows, avalanches, rockfalls and landslides (Table 1) can be dated with at least one-year resolution using this method (Lang et al., 1999; Kaczka et al., 2010).

Because tree rings represent the typical structure of wood (xylem) used for dating purposes, we find it important to briefly describe their basic anatomy. Xylem is 
Table 1. Typology of catastrophic slope-movements based on Varnes (1978) and Kukal and Pošmourný (2005); edited by the authors to fit the prevailing focus and terminology of current dendrogeomorphological case studies.

\begin{tabular}{|c|c|c|}
\hline $\begin{array}{c}\text { Type of catastrophic } \\
\text { slope-movement }\end{array}$ & Characteristic features & Subtypes \\
\hline Landslide & $\begin{array}{l}\text { Distinct slip surface(s), where shear strain takes place, is } \\
\text { formed between transported material and underlying layers. }\end{array}$ & $\begin{array}{l}\text { Rockslide } \\
\text { Debris-slide } \\
\text { Earthslide }\end{array}$ \\
\hline Flow & $\begin{array}{c}\text { The deformation of transported material (which usually partly } \\
\text { consists of water) takes place in whole masses. Surfaces of } \\
\text { shear are short-lived, closely spaced and usually not pre- } \\
\text { served. }\end{array}$ & $\begin{array}{c}\text { Debris flow } \\
\text { Debris flood } \\
\text { Earth flow } \\
\text { Soil and rock creep } \\
\text { Slope sagging }\end{array}$ \\
\hline Fall & $\begin{array}{l}\text { Falling, rolling and bouncing of single stones or layers; at least } \\
\text { some part of the transport is carried out by free fall. }\end{array}$ & $\begin{array}{l}\text { Rockfall } \\
\text { Debrisfall } \\
\text { Earthfall }\end{array}$ \\
\hline Avalanche & $\begin{array}{c}\text { Abrupt movement of snow downhill with a path longer than } 50 \\
\mathrm{~m} \text { and speed of at least } 10 \mathrm{~m}^{-1} \mathrm{~s}^{-1}\end{array}$ & $\mathrm{x}$ \\
\hline
\end{tabular}

formed as a result of the activity of cambium - the lateral meristem - which is responsible for the secondary growth of trees (Pallardy and Kozlowski, 2008). For a strong seasonal climate (e.g., boreal or temperate climatic zone, semiarid climates), the activity of cambium is restricted only to a specific part of the year - the growing season and for the rest of the year (dormancy), it ceases (Schweingruber, 1996). The onset and duration of cambial activity is hormonally driven, and the production of hormones is governed by temperatures and photoperiod (Rossi et al., 2006; Pallardy and Kozlowski, 2008). Xylem cells created at the beginning of the growing season have a primarily transporting function, which results in their unique shape; along their transversal cross-section, they are isodiametric and thin-walled. On the other hand, cells formed during summer months serve as mechanical support for trees and are flattened and thick-walled (Schweingruber, 1996). The formation of alternating layers of these two types of cells creates the typical structure of tree rings. There are three different functional types of cells present in the xylem structure (Pallardy and Kozlowski, 2008): parenchyma (transports water horizontally and stores substances), schlerenchyma (mechanical support) and trachea (vessels) and tracheids (transport water and nutrients upward from the roots to the crown). The spatial structure and proportion of the previously mentioned types of cells differs greatly between angiosperms and gymnosperms. Tracheae are not present in the xylem of gymnosperms, which makes their structure simpler and tree rings often more optically distinguishable (Schweingruber, 2007).

The fundamental principle of mass-movement dating is that the energy of an event leads to a change in local ecological conditions, which has a strong influence on plant growth. Trees affected by this change have to adapt, which means changing their growth parameters (Gärtner, 2007a). This idea was originally defined by the so-called Process-Event-Response principle (Shroder, 1978). In this case, the Process indicates geomorphological factors (e.g., mass-movement, earthquake, flood, erosion), which are very important Events in the life of a tree (it can cause, e.g., tilting, mechanical damage to cambium, or competition-pressure decrease). Wooden plants adapt to new conditions by changing their rate of cambial activity and xylem structure. Because there is a clear logical link between Process, Event and Response, these abrupt changes can be used to reconstruct the original Process (Shroder, 1978), and different reactions of trees can therefore serve as a good tool for the estimation of the time of occurrence of a geomorphological event.

The aim of this article is to provide a comprehensive review of (i) the macroscopic and microscopic reactions of trees to mass-movement disturbance and (ii) recent dendrochronological research of rapid mass movements in terms of type of mass movement, regional focus, methods used and dating resolution achieved.

\section{METHODOLOGY}

We attempted to build the most complete list of case studies focused on mass-wasting dating through dendrochronological methods. However, our effort barely reached total completion because the number of studies using dendrochronological methods is enormous, and in many studies, dendrochronology is combined with other dating techniques and serves only as a supplementary tool. Moreover, any complete list would gradually lose its value over time because new articles are rapidly being published. Our meta-analysis is therefore based on as broad sample of dendrochronological case studies focusing solely on the dating of mass-wasting events as possible. Only case studies sensu stricto in which dendrochronology was the dominant dating method were involved.

The principle parameters of the involved studies that were evaluated were the mechanism of slope processes, analysed growth reactions, temporal extent and resolution of results, geographical locality, species and sampling strategy. To identify and analyse the relationships be- 
tween the processes and dating methods used (including data resolutions and covered time spans), we used redundant discriminant analysis implemented in CANOCO software (Ter Braak and Šmilauer, 1998). Because most of the variables were categorical, they were transformed into "dummy" variables (Lepš and Šmilauer, 2003).

To enhance the validity of the results, a special rule had to be set for the inclusion of analysed types of mass movement and markers. To do this, the requirement of a minimum of 10 studies for mass movement types was set - if fewer than ten studies focused on a single type of movement, they were not involved in the meta-analysis because that type of research activity was not adequately represented. An exception to this rule was made only if (i) the research was focused on areas with the concurrent origin of two or more different types of slope processes or (ii) if the mechanism of the process and procedures used for dating were very similar to that used to study another type of the event. In this case, two similar groups were merged. The same rule, with a threshold of only 5 studies, was set for markers of disturbances because the number and variability of the markers used are higher than those of mass-wasting type.

\section{RESULTS}

\section{Overview of macroscopic and microscopic markers of mass movements in tree rings}

\section{Irregular shape of tree-rings}

Eccentrically shaped tree rings are characteristic of trees growing on slopes, where trees are subjected to soil creep or mass movement processes. Their stems are usually deflected toward the direction of mass movement, and during subsequent growth, they become curved near the bottom of the trunk (Schweingruber, 1996). This curvature occurs because the imbalanced position of the deflected tree forces the formation of elliptical tree rings during the following growing seasons. Tree-ring shape and the rate of ring eccentricity can serve as tools to determine the year when a tree was inclined (Fig. 1a).

Tree-ring eccentricity can be quantified and analysed by means of so-called eccentricity indices, whose specific form differs among researchers (Table 2).

An abrupt increase in the value of indices indicates the year of the inclination of a tree.

The main advantage of Schweingruber's (1996) formula is its simplicity. However, tree rings are usually very narrow along the upper part $\left(\mathrm{R}_{\mathrm{u}}\right)$ of the inclined stem (in conifers), which makes their measurement very difficult and very often leads to mistakes (Braam et al., 1987). The application of the equation developed by Braam et al. (1987) faces this problem but requires the core to be extracted in a direction perpendicular to the inclination (which is not always performed). All of the equations listed can be used for the quantification of the eccentricity of coniferous tree rings; if angiosperms are used for den- drochronological research, the equations must be adjusted with regard to the specific form of tension wood formed by these species (Pallardy and Kozlowski, 2008).

\section{Abrupt growth changes}

Because tree-ring width is inter alia driven by external factors affecting trees (Cook and Kairiukstis, 1990; Schweingruber, 1996), this parameter has traditionally been the main and principle indicator of disturbances.

Masses transported during events on a slope usually have huge kinetic energies. Although the majority of mature trees are destroyed, juvenile trees are usually not damaged to the same extent due to the flexibility of their stems. In the following spring, the survivors can use more of the local resources because of the decrease in competition pressure. As a result, a sudden increase in tree-ring width occurs (Stoffel et al., 2005a, 2005b; Casteller et al., 2007; Šilhán and Pánek, 2008). Other ways in which a mass-movement event can induce wider tree-ring formation are, for example, the accumulation of fertile soil near trees (Gärtner, 2007a) or the increase in water content in accumulated layers (Fantucci and Sorriso-Valvo, 1999).

Some trees affected by the energy of mass movement can be seriously damaged (e.g., decapitation, tearing of roots) but not killed, which results in the reduction of their cambial activity in the following years (Fig. 1b).

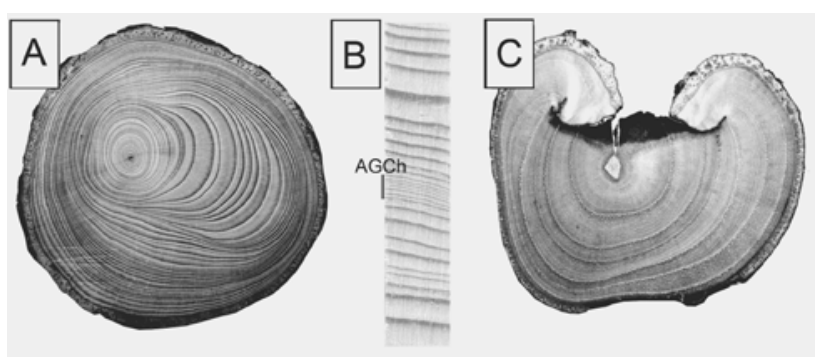

Fig. 1. Macroscopic changes in tree rings: (a) changes in eccentricity; (b) abrupt growth change (reduction) in tree-ring width (AGCh), and (c) growth injury (scar).

Table 2. Different equations used for quantification of eccentricity of a single tree-ring; $R_{D}$ - tree-ring width measured in downslope orientation, $R_{U}$ - tree-ring width measured in upslope orientation, $R_{P}-$ treering width measured in orientation perpendicular to slope.

\begin{tabular}{ccc}
\hline Equation & Citation & $\begin{array}{c}\text { Value of a } \\
\text { circle }\end{array}$ \\
\hline $\mathrm{I}_{\mathrm{ex} 1}=\frac{R_{D}}{R_{U}}$ & Schweingruber, 1996 & 1 \\
$\mathrm{I}_{\mathrm{ex} 2}=\frac{R_{D}-R_{P}}{R_{D}+R_{P}}$ & Braam et al., 1987 & 0 \\
$\mathrm{I}_{\mathrm{ex} 3}=\frac{R_{D}}{R_{D}+R_{U}}$ & Alestalo, 1971 & $1 / 2$ \\
\hline
\end{tabular}


Additionally, the burial of stem bases with the huge masses transported and accumulated by an event can lead to the formation of narrow tree rings (Gärtner, 2007a) as a result of strong mechanical pressure on the cambium and reduced access to air for roots (Strunk, 1997). The inclination of the tree stem can also result in abrupt growth reduction if tree-ring widths are measured perpendicularly to the inclination (measurements should not be performed in the up- and downwards directions because the tree-ring width can be eccentrically deformed there). This is because the formation of reaction wood and lignification of cell walls is energy-consuming (Schweingruber, 2007).

\section{Reaction wood formation}

If a tree stem is affected by mechanical stresses (such as pressure or tension), the anatomical structure of wood changes, and so-called tension wood (angiosperms) or compression wood (gymnosperms) is formed. Together, these are termed reaction wood (Schweingruber, 1996). Because their formation is usually the result of stem inclination, the relationship between tree-ring eccentricity and reaction wood is very explicit (Duncker and Spiecker, 2008).

Compression wood is formed in the area of the cambial zone of gymnosperms that is affected by compression, i.e., on the lower side (Stoffel and Bollschweiler, 2009a). The cells are usually isodiametric, typically with thickened cell walls (Schweingruber, 1996), which macroscopically results in an apparently darker colour. Intercellular spaces occur between cells frequently (Fig. 2a). Another typical feature is the vast amount of lignin impregnating cell walls, which allows for the straightening of tree stems but decreases the permeability of the walls (Pallardy and Kozlowski, 2008).

On the other hand, the tension wood of angiosperms is usually formed on the upper part of the inclined stem, where the increased activity of the cambium usually occurs after inclination (Heinrich and Gärtner, 2008; Stoffel and Bollschweiler, 2009a). Typical features are low lignin content and the presence of gelatinous fibres (Heinrich and Gärtner, 2008). Unfortunately, tension wood is very difficult to recognise macroscopically - as a result, and if possible, the reaction wood of gymnosperms is more frequently used for dendrochronological purposes.

Using reaction wood as an indicator of disturbance has some important advantages. First, if the disturbance occurred during the growing season, results with a resolution of better than one year can be obtained by analysing the position of the first reaction wood cells inside a tree ring. However, the risk of delayed reaction wood formation is also very important; if a tree is damaged by mass movement, different adaptations can proceed first after the event (such as an abrupt decrease in growth), and the formation of reaction wood can be delayed for a few years (Carrara and O'Neill, 2003). Significant potential also lies in the possibility of estimating mass- movement intensity and direction (Heinrich and Gärtner, 2008; Duncker and Spiecker, 2008).

\section{Exposed tree roots}

Although the use of exposed tree roots (as well as adventitious roots) was infrequent in studies directly focused on mass-wasting dating (fewer than 5 studies), we provide a short explanation of the principles of dating based on them because exposed roots have proved very useful in other geomorphological situations, e.g., the dating of gully evolution (Malik and Matyja, 2008) or estimation of erosion rates (Bodoque et al., 2005).

The exhumation of roots occurs in the transport and source zones as a result of mass-movement events. These roots are then affected by different ecological conditions, which results in changes in the anatomical structures of wood (Hitz et al., 2008).

Normally, tree rings in roots are often hardly distinguishable, narrow and feature indistinct layers of latewood (Schweingruber, 1996) and the cells forming them are usually larger (higher vessel lumen area) with thinner walls (Hitz et al., 2008) (Fig. 2c). In contrast, the wood of exposed roots resembles the wood of stems and branches. However, the presence of very narrow or missing rings is very common in roots, which makes the measurement of tree-ring width difficult and cross-dating almost impossible (Bodoque et al., 2005); therefore, only

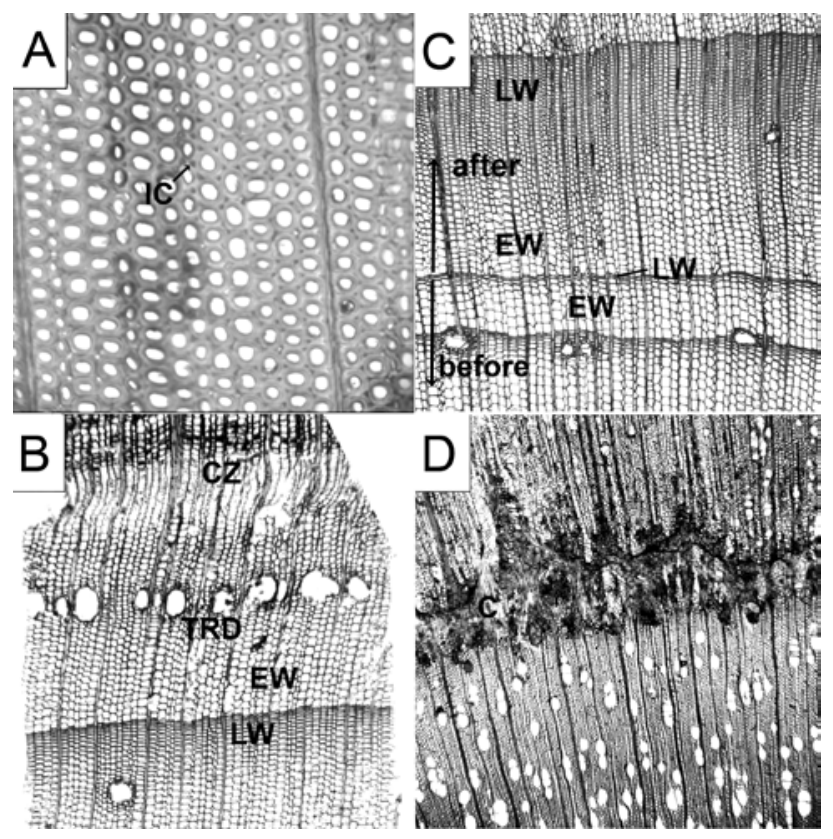

Fig. 2. Response of tree-ring anatomy to disturbances: (a) reaction wood; (b) traumatic resin ducts formed several weeks (2-4) after experimentally induced injury; (c) comparison of wood anatomy in roots before (thin late-wood cells zone) and after (broad late-wood cells zone); (d) callus tissue; (a-c: Picea abies, d: Betula pendula; magnification of "a": 200x, "b-d": 50x). Abbreviations: IC - intercellular spaces; EW - early wood; LW - late wood; CZ - cambial zone; TRD traumatic resin ducts; $\mathrm{C}$ - callus. 
living exhumed tree roots should be sampled (Malik and Matyja, 2008).

The risk in analysing exposed tree roots is that they could be exposed only because of their gradual radial growth, without the effects of external forces. The methodology proposed by Gärtner (2007b) can be used to differentiate these two situations. To avoid the sampling of tree roots exposed due to stem growth, samples should be taken at least $1.5 \mathrm{~m}$ from stem base (Bodoque et al., 2005). This distance cannot be dogmatically accepted; it strongly depends on the specific conditions of the associated microtopography and the sampled tree. For example, if the estimation of gully erosion intensity is the aim of the dendrochronologist, very special care must be given to the selection of the position of root cutting to avoid the under- or overestimation of erosion rates and volumes (Vandekerckhove et al., 2001). Very useful information, which can be achieved by studies of exposed tree root, is whether it was exposed all at one time (one fast event) or gradually part-by-part (slow continuous process - e.g. gully erosion). Taking more samples in different positions from one exposed root can help to differentiate these two situations (Malik and Matyja, 2008).

\section{Tree response to a burial event - adventitious tree roots}

Trees growing in area where the accumulation of transported masses takes place are usually exposed to frequent burials, which results in changes in tree-ring widths and wood anatomy. These are mainly dependent on the amount of burial material, physical and chemical structure, the periodicity of burial and also on the phenological phases during which the burials occurred (Kent et al., 2001).

The situation is analogous to the exhumation of tree roots - after burial, we can expect the formation of cells with larger vessel lumen areas and thinner cell walls (Friedman et al., 2005). If samples are taken from the level of the former stem base, tree rings may be hardly distinguishable and very narrow (Friedman et al., 2005). Picea abies (L.) Karst. reacts by an apparent shortening of tree rings after burial by fine-grained material of $10 \mathrm{~cm}$ thickness and dies if it is covered by 1.6-1.9 $\mathrm{m}$ of material (Strunk, 1997). If burial exceeds a critical level, dead tree stumps can then be used to estimate the minimum age of an event (Yoshida et al., 1997).

The main consequence of a burial event is the reduction in the roots' access to air; as a result, a tree forms new roots in accumulated layers near the soil surface. These tree roots are called adventitious and can be used by dendrochronologists for dating purposes (Gärtner, 2007a). The cross-section of the stem in a vertical layer of adventitious root is taken and the first anatomical sign of its formation is identified (Strunk, 1997). The problem is that there can be a prolonged lag between the event and the beginning of the formation of these tree roots. There- fore, the results obtained from adventitious tree roots should normally be interpreted as minimum ages only (Gärtner, 2007a).

\section{Traumatic resin ducts (TRD)}

Resin is a chemical substance that is produced by conifers under active stress, and resin ducts, the cellular formations responsible for its production, can be found scattered in the wood of many coniferous species (Schweingruber, 2007; Pallardy and Kozlowski, 2008). In the case of a strong external factor inducing their formation, some species (Picea abies, Larix decidua Mill., Abies alba Mill.) form coherent tangentially oriented traumatic resin ducts (TRDs) (Stoffel, 2008), which can be used for dating purposes (Fig. 2b).

The most important information recorded in TRDs is their position inside a tree ring; therefore, they are very often used to achieve better than one-year resolution in dating (Stoffel et al., 2006; Szymczak et al., 2010). The basic principle is that the TRDs in one of the first layers of cells of a specific tree ring indicate mechanical damage to the tree during the previous dormancy; TRDs occurring in the second half of the tree ring indicate that a disturbance took place during the growing season (Stoffel et al., 2006; Szymczak et al., 2010). However, a tree's response to disturbances seems to be complex and species-specific (Gärtner and Heinrich, 2009). While some species form TRDs after winter disturbance events immediately at the beginning of the growing season (e.g., larch), others respond with a lag, and TRDs are detectable only in a part of their tree-ring area (Stoffel and Hitz, 2008; Gärtner and Heinrich, 2009). Additionally, the persistence of TRD formation in tree rings following the year of the damage depends on species and massmovement type (Schneuwly et al., 2009).

\section{Growth injuries}

Clastic material, logs and other objects transported by the energy of mass movements hit, abrade and injure tree stems, which can result in local damage to cambium and xylem. Nearby surviving cambium reacts by forming irregularly shaped cells (callus) (Fig. 2d), which serve to fill the damaged segment (Gärtner, 2007a). Tree rings formed after injury have a very typical and "incomplete" shape (Fig. 1c).

The speed at which injuries are healed depends on the size and the speed of the moving clast, the speed of tree growth and specific features and processes of secondary bark (e.g., peeling; Stoffel and Perret, 2006). Problems for the dendrochronologist appear when an entire injury is healed with callus and any obvious signs of injury are no longer externally visible on the stem. Healed injuries can be studied effectively only through the sampling of cross-sections (Bollschweiler et al., 2007) because if cores are extracted, the identification of injury is difficult. 


\section{Colonisation}

If a mass-movement event is very strong and destructive, it is capable of destroying all vegetation in the affected area, which makes the utilisation of the abovementioned indicators of disturbance almost impossible. In this case, the age structure of the established stand can be useful - if an event truly destroyed all surrounding trees, the age of the oldest tree now growing in the area provides the minimum age of the event (Bollschweiler et al., 2008). The same presumption can also be used for the minimal dating of fresh surfaces created in accumulation zones, e.g., rockslide cones (Van der Burght et al., 2012). The length of the lag between the event and the germination of the first seedling (ecesis) depends on the climatic and edaphic conditions of the area (mainly grain-size of substratum) and the availability of seeds (Sorg et al., 2010). The species composition of the surrounding source forest sites plays a crucial role because different species have different eceses (Van der Burght et al., 2012). The frequency of events can also be indirectly assessed by the age distribution of trees and shrubs growing in the area affected by the mass movement (Voiculescu and Ardelean, 2012).

\section{Mass movement dating characteristics}

A total of 69 scientific studies dealing with the dendrochronological dating of various types of mass movements were evaluated (Appendix and Fig. 3). Most of them address debris flows (including debris floods and lahars - 22), avalanches (17) and landslides and rockslides (17). The highest number of studies are from Switzerland (19) and the Alps. A preference for gymnosperms for sampling purposes is clearly visible - at least one species was a gymnosperm in 52 (more than $75 \%$ ) case studies. From this point of view, the most "popular" were Picea sp. (27), Pinus sp. (20) and Larix sp. (19). Angiosperms were more common only in the case of landslide dating, and the most used species were Alnus sp. (7), Betula sp. (6) and Fagus sylvatica L. (6). The markers used to date events were typically growth injuries and the onset of callus formation (51) and abrupt growth changes (51). Reaction wood (45) and TRD (27) are also common

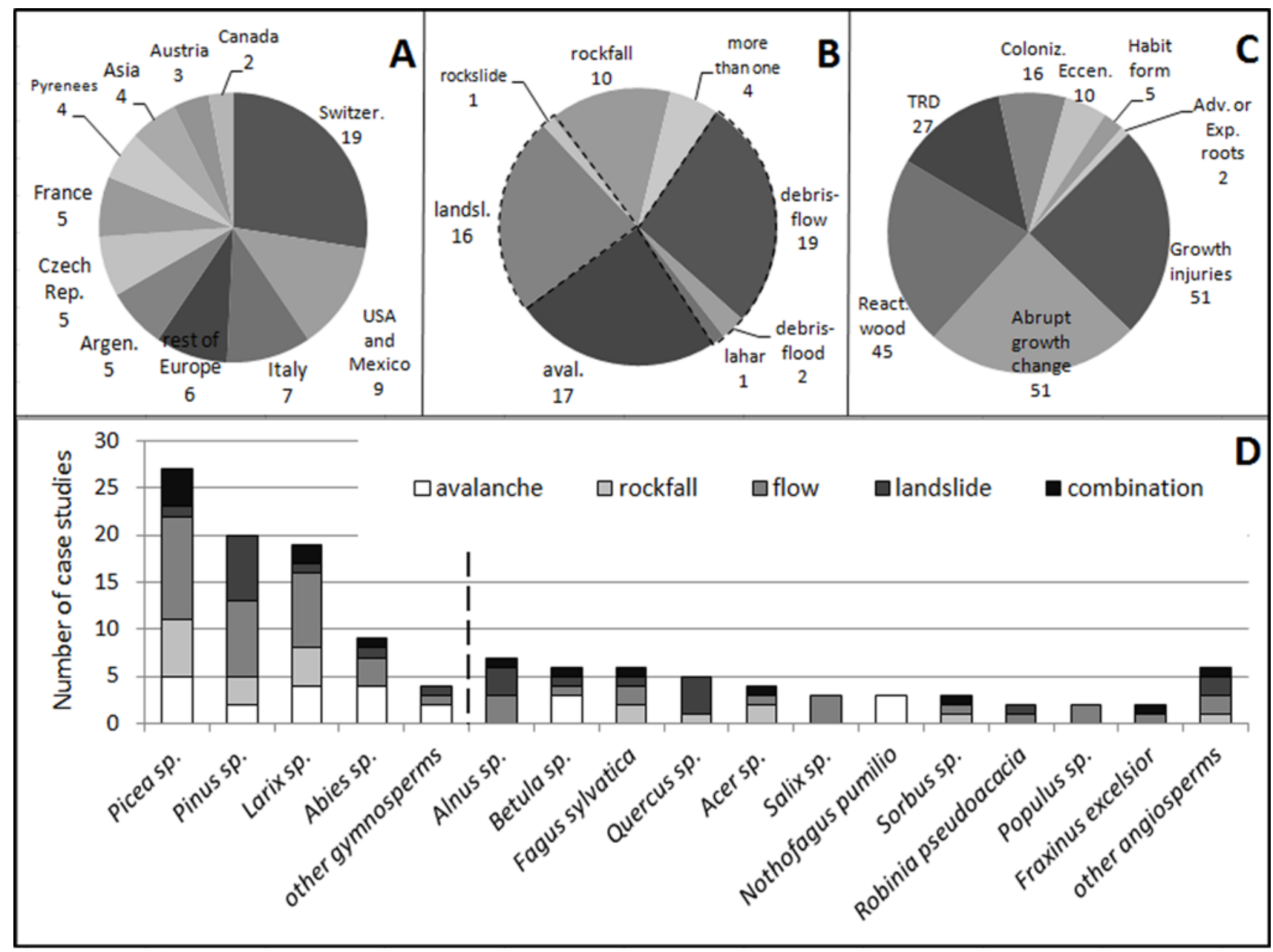

Fig. 3. Parameters of studies according to $(A)$ country, $(B)$ type of the event, $(C)$ microscopic and macroscopic markers used for dating and $(D)$ dated species. For detailed characteristic of studies see Appendix. 
in the analyses. Although a resolution of better than one year can be achieved through these last two markers of disturbance, this great potential of modern dendrogeomorphological analyses was only rarely (11) used by researchers, so the majority of the results exhibit one-year resolution.

Taking cores is generally preferred over the destructive sampling of wedge-cuts or cross-sections (discs). However, if eccentricity is the key marker of massmovement, the problem of missing the pith of core can be especially important. The third "sampling strategy" is simply the evaluation of the external habit (appearance) of trees and shrubs; specific forms (e.g., candelabra tree form, decapitated trunks) are typical evidence of former slope disturbances. However, the dating of events cannot be achieved in this way.

The ordination plot of redundant discriminant analysis (Fig. 4) shows correlations between mass-wasting types and their dating characteristics. As the score on a given axis increases, a higher correlation between the corresponding mass-wasting type and dating method can be expected. Flows and rockfall are mostly dated using TRDs and growth injuries (high negative scores on Axis 1 ), whereas landslides are usually identified by abrupt

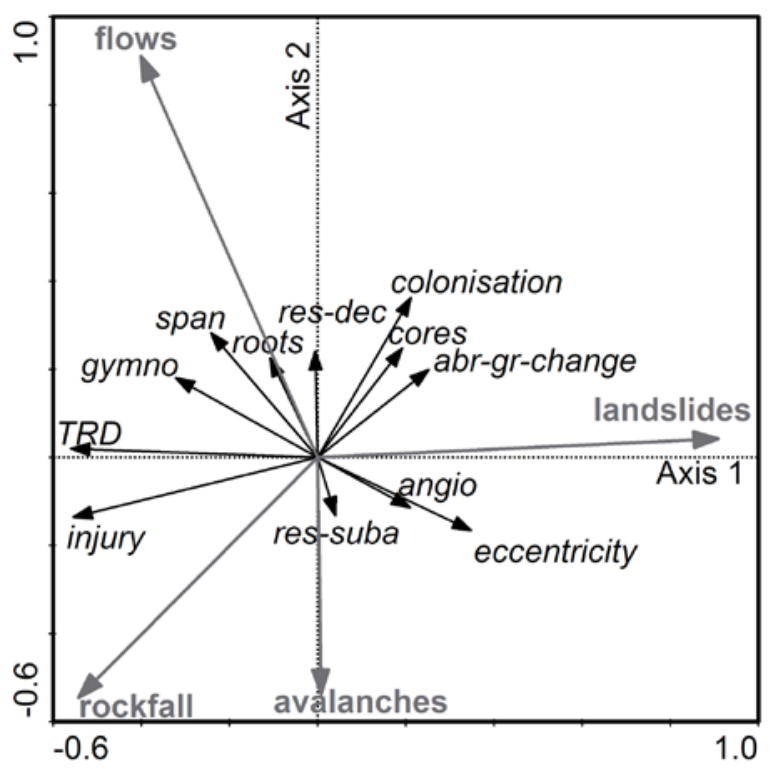

Fig. 4. Redundant discrimination analysis ordination plot. Arrows indicate directions of variance; the longer they are and the more acute angle they have with corresponding axis or with other variable (e.g. arrow), the more are correlated. Axes represent the main directions in variability of the given set of variables. First two axes cover $75 \%$ of mass-wasting type - methodological characteristics variance. For the sake of simplicity, variables with the lowest scores on both axes are suppressed (reaction wood, habit, annual resolution, cross sections). Abbreviations: gymno - gymnosperms; angio - angiosperms; res-dec - decadal resolution; res-suba - subannual resolution; abr-gr-change abrupt growth change. growth changes and changing eccentricity (high positive scores on Axis 1). Colonisation is mostly used as a data source for dating flows. Avalanches are most frequently determined through reaction wood formation and injuries (correlated along third axis of RDA scheme - not shown). While angiosperms are mainly used for landslide dating, gymnosperms are frequently sampled in cases of flow and rockfall.

\section{Snow avalanches}

Early studies regarding snow avalanches have been performed in the northern U.S., particularly in Wyoming, Colorado and especially Glacier National Park (Montana) (Butler and Malanson, 1985), which still attractive for researchers (Reardon et al., 2008; Butler and Sawyer, 2008). However, since the turn of the millennium, attention has also been aimed at other mountains, e.g., the Alps (Casteller et al., 2007; Corona et al., 2010), the Pyrenees (Muntán et al., 2009) and the Andes (Mundo et al., 2007; Casteller et al., 2011).

The goal of the study of avalanches is to determine the frequency of avalanche events and the extent of their paths; dendrochronology can use information about ages and the density of trees for this purpose. Paths usually record lower average ages of trees (Casteller et al., 2007) and lower tree density (Mundo et al., 2007). For the proper dating of an event, almost all of the markers mentioned in the previous chapter, except for adventitious roots, can be used (Casteller et al., 2007), depending on the specific situation.

The most traditional way to statistically analyse data for dating purposes was first described by Shroder (1978) and requires finding the proportion of disturbed trees among all the trees growing in an area (with a one-year resolution). Due to temporal changes in sample depth (meaning that the number of analysed trees is not the same for all the years of the analysis because the years of germination are usually not the same), this is effectively necessary; the method based only on the absolute count of affected trees would strongly underestimate avalanches in years when there were only few sampled trees growing (this usually means older periods). Shroder's (1978) procedure can also be used to study landslides (Stefanini, 2004) or debris floods (Mayer et al., 2010). The threshold value should usually be set, in the case of avalanches, between 10 and 40\% (Butler and Sawyer, 2008); traditionally, it has been set at 10\% (Reardon et al., 2008). Very detailed methodological research on the problem of setting the appropriate level of this index performed by Corona et al. (2012) pointed to the need to increase the threshold with decreasing sample size; otherwise, many past avalanches can be omitted and potential noise (identification of "false" events) can occur. The other statistical analysis approach is based on a special "scoring" scheme, which assigns points to years according to the number and severity of indicators of the avalanche and the total amount of disturbed trees (Casteller et al., 2011). 
The dating of avalanches can broadly use loads of dead wood (i.e., the broken trunks of trees growing in the path before the fall) to estimate the ages of their breakage by means of cross-dating. To determine whether their death was really avalanche-induced, the analysis of the azimuth of their deposition in relation to the expected azimuth of the avalanche can be used (Reardon et al., 2008; Corona et al., 2010).

\section{Rockfall}

Research activities focused on rockfalls are mostly restricted to Europe (predominately the Alps). Data about frequencies of rockfall derived from tree rings spans across the last four centuries (Stoffel et al., 2005b).

Falling clasts can have huge kinetic energies and the capacity to seriously damage trees. As a result, decapitated habits and surface injuries are typical features of trees in an affected area (Stoffel et al., 2005b). If a crown is broken, two adventitious shoots usually emerge and continue vertical growth. After a few years, the habit closely resembles a street light, which is why it is called a "candelabra tree form" (Schweingruber, 1996). These adventitious shoots can be very easily used to estimate the minimum age of an event (Schweingruber, 1996). The breaking of the crown is usually the consequence of a frontal hit to the upper parts of a tree, but it can also be caused by the vertical sinusoidal transmission of kinetic energy affecting the lower parts of the stem (Dorren and Berger, 2006; Stoffel and Bollschweiler, 2008). In addition to habit form, many other dendrochronological pointers of the timing of an event can be used to accurately date a rockfall, e.g., abrupt growth changes, scars, reaction wood and (in the case of conifers) TRDs. Because this type of mass movement can occur both during dormancy and a growing season, the last three mentioned indicators of rockfall can be particularly useful for dating with better than one-year resolution (Stoffel et al., 2005c; Schneuwly and Stoffel, 2008b; Moya et al., 2010).

The dendrochronological dating of rockfall must take into account the fact that this slope movement transports single clasts differing in size rather than some type of compact layer. One clast can damage more than one tree during transport, but on the other hand, it can pass a forest belt without inflicting any hits. The probability of the second situation decreases with the increasing average DBH of trees; thus, the area where samples are collected should be belt-shaped with different widths depending on the average DBH (for specific values of width/DBH see Moya et al., 2010). Additionally, the number of growth reactions per year reveals almost nothing about the changes in the frequency of events because it also depends on changes in DBH. To obtain accurate data, DBH, should be used as a weighting tool, as shown in the following equation (Stoffel et al., 2005b):

$$
R R_{d t}=\frac{\sum G R_{d t}}{\sum E D_{d t}}=\frac{\sum G R_{d t}}{\left(\frac{D B H}{A} T_{d t}\right)}
$$

where $R_{\mathrm{dt}}$ stands for rockfall rate, $\mathrm{GR}_{\mathrm{dt}}$ is the number of documented rockfall events during decade $t, \mathrm{ED}_{\mathrm{dt}}$ is the exposed diameter of the tree at the beginning of decade $\mathrm{t}, \mathrm{DBH}$ is the diameter at the breast height, $\mathrm{A}$ is the number of tree rings formed at the breast height in the year of the sampling and $\mathrm{T}_{\mathrm{dt}}$ is the number of tree rings formed at the breast height at the beginning of the decade. This equation can be modified if necessary to obtain a resolution of better than one decade (Perret et al., 2006; Schneuwly and Stoffel, 2008a).

\section{Flows}

Pioneer studies were performed during the 1980s in California (Hupp, 1984) and during the 1990s in the Dolomites (Strunk, 1997). Currently, the highest density of research activity occurs in Switzerland, where up to fourcentury-long chronologies of debris flows have been established (Stoffel et al., 2005a).

Usually, there are huge masses of sediments accumulated in the depositional zone of flows, which can cover stem bases. Consequently, the formation of adventitious roots often occurs. Their analysis, together with the evaluation of the ages of trees colonising specific layers, is a strong tool used to date several generations of flows (Sorg et al., 2010). Additionally, exposed tree roots, scars, abrupt growth changes and TRDs can be successfully used for dating purposes (Bollschweiler et al., 2007; Sorg et al., 2010; Stoffel and Bollschweiler, 2009b).

Scars, reaction wood and other growth reactions are, in the case of flows, usually concentrated near the stem base, not higher than the thickness of the flow during the event. This is the main difference from a rockfall, where injuries can occur vertically along the whole stem (Stoffel and Perret, 2006). The activity of different types of flows also affects spatially compact zones (this means almost all trees in their way), which holds potential for the dendrochronological analysis of temporal changes in the extent of an affected area (Bollschweiler et al., 2011). However, special attention must be paid if debris contains an excessive amount of water (so-called hyperconcentrated flows); some trees growing inside an event trajectory may report no anomalies because they have been affected not by clasts but only by water (Bollschweiler et al., 2007).

\section{Landslides}

The typical manner in which the majority of landslides affect trees is by inclination. The azimuth of inclined stems is a very good indicator of mass-movement type; due to translational movement, almost all trees are inclined toward the valley. On the other hand, if rotation was the dominant mechanism, trees should register a 
bimodal or multimodal distribution of stem directions (Fantucci and Sorriso-Valvo, 1999; Van Den Eeckhaut et al., 2009). Almost all of the growth reactions mentioned in the previous chapter can be used to date landslides, but in the case of abrupt growth changes, typically only sudden reductions in tree-ring widths occur (Van Den Eeckhaut et al., 2009) because a landslide only rarely results in the total destruction of trees and a related decrease in competition. Because the majority of case studies involved in the meta-analysis focused on landslides in areas covered by angiosperms (or Pinus sp., which does not form resin ducts traumatically), TRDs are also rarely used.

\section{DISCUSSION AND CONCLUSIONS}

The dendrochronological dating of a mass-movement event involves important differences in the types of movement addressed. While high-energy events causing severe debris impacts to trees are mainly dated by TRDs and growth injuries (callus), relatively slower massmovements (landslides) are mostly detected by changes in growth rate and changes in eccentricity. Avalanches are in most cases indicated by reaction wood and growth injuries. Only the dating of avalanches and to some extent also debris flows can use loads of dead wood (Yoshida et al., 1997; Reardon et al., 2008). From a conceptual point of view, the direct markers resulting from the impact of mass movements on trees record events immediately. On the other hand, several indirect markers are formed with a lag. Their relation to certain events ranges from very strong (e.g., TRDs, reaction wood) to more-or-less questionable. For instance, eccentricities or exposed roots are usually frequent in a given area as a result of soil creep or the radial growth of roots, irrespective of mass movement (Gärtner 2007b). It is obvious that the use of a given marker depends on the nature of the mass-movement type. Therefore, high-energy, rapid events are often dated using direct markers and markers with strong links to the events, whereas landslides can be dated mostly by using indirect markers, often with relatively weaker relations to the events (e.g., eccentricity).

It is not only the methods used but also the sampling strategy employed that differs between types of mass movement. If dating an avalanche, landslide or flow is the aim of the researcher, two cores per tree are usually extracted (one in the downslope direction and one perpendicular to the slope azimuth). The exceptions are some recent studies focusing on landslides attempting to record successive changes in eccentricity (Lopez Saez et al., 2012b, 2012c), which are based on 3 to 4 cores per tree. On the other hand, in the case of rockfall, four cores are almost always taken from a stem because the number of tree rings overgrowing scars and forming callus and the difference in the number of tree rings on the scar side and opposite side of the trunk must be determined (Schneuwly and Stoffel, 2008a). Usually, a core along the per- pendicular direction is also taken. As a result, the dendrochronological dating of rockfalls (which is often based on scars) is usually based on a greater number of samples than that of other types of mass movement. Because the impact energy can abrade some tree rings, this dating method can provide only the maximum age of an event.

Great "irregularities" also exist in the geographical distribution of research activities. Although the potential of tree rings as proxy data for mass movement events was first revealed in the U.S. (Butler and Malanson, 1985), these methods have expanded from North America and currently a second "core" of dendrochronological research has been established in Europe. Although research activities focusing on avalanches and landslides are dispersed all around the world, dendrochronological research on rockfalls and flows in particular has become greatly concentrated in the Swiss Alps over the last 5-10 years.

The high temporal resolution of dating is an important advantage of dendrochronology; however, there is still some risk associated with the misinterpretation of the causal processes that induce the formation of a given marker. First, many non-geomorphological processes (e.g., biotic, meteorological) can leave apparently similar marks in tree-ring structures. Filtering out of this noise constitutes a very important challenge for dendrochronologists. For abrupt growth changes, comparison with reference tree-ring curves constructed from adjacent undisturbed trees is traditionally applied (Cook and Kairiukstis, 1990). However, for other markers, there are no such well-established procedures. For microscopic dating (TRDs, reaction wood, injuries) and eccentricity-based techniques, the position/orientation of markers with respect to the direction of impact may be indirectly useful (Duncker and Spiecker, 2008) but only in the case of landslides, avalanches and flows. Rockfall involves the irregular bouncing of single rocks and some impacts on the lower (i.e. opposite) side of a stem result from the rebounds of clastic material (Stoffel et al., 2005b).

Because abrupt growth changes are some of the most common markers used for dating mass-movement events, the risk of mistakes caused by poor measurement must be taken into account. Using dendrochronological crossdating principles, most of these errors can be identified (Grissino-Mayer, 2001). Trees and shrubs seriously damaged by mass movement can form number of very narrow tree rings during subsequent years, which can hardly be distinguished if a sample is prepared for traditional macroscopic analysis (i.e., sanded and measured on a positioning table under a binocular microscope). Some tree rings may be overlooked by the dendrochronologist, and mistakes in the estimated years of the slope activity can be made. The risk of poor measurement can be greatly reduced if permanently stained sections of whole cores are prepared first and the ring widths on them measured. The preparation of these long sections is the same as that for "traditional" sections of a fractional part of a sample described else- 
where (Schweingruber, 2007); the former, however, requires (i) a microtome that is long enough to mount a whole core (Gärtner and Nievergelt, 2010) and (ii) laboratory slides that are also sufficiently long. Unfortunately, most producers of laboratory equipment distribute thin $(0.1 \mathrm{~cm})$ slides that are maximally approximately $8 \mathrm{~cm}$ long, but we have also had very good experience with thicker glass $(0.2$ and $0.3 \mathrm{~cm})$, which is readily available in most glazier shops. If tree-ring widths are measured on these sections under a binocular magnifying glass (magnification $20 \times$ ), tree rings measuring nearly $4 \mu \mathrm{m}$ can be very easily distinguished and measured (Fig. 5).

Because "the past is the key to the future", data regarding former mass-movement events can be very useful and are of special importance. One of the main advantages of dendrochronology in comparison to other methods of absolute dating is the temporal resolution of results (Lang et al., 1999). Traditional methods of the macroscopic analysis of tree-rings can achieve one-year resolution; in the case of the microscopic evaluation of anomalies in cell anatomy, more accurate results can be obtained. In the case of avalanches (which occur almost exclusively during dormancy), microscopic growth reactions can help to filter out years when a tree may have been affected by summer disturbances (e.g., storms), leaving markers similar to those left by an avalanche. In the case of other types of mass movements, growth reaction can help achieve one-month resolution if the associated events took place during the growing season. In this case, special care must be taken to reduce the risk of underestimating or (more frequently) overestimating the time of an event (Kaczka et al., 2010). Many studies have used TRDs, reaction wood or the microscopic analysis of scar formation. However, the majority have produced analytical results with only one-year resolution, and the main potential of microscopic growth reactions has been neglected. On the other hand, both the lag in and persistence of TRD and reaction wood formation are speciesspecific and differ along the stem, which is a source of uncertainty in dating (Heinrich and Gärtner, 2008; Gärtner and Heinrich, 2009; Schneuwly et al., 2009). Mainly in places where two or more types of mass movements are common and differ only in the season of their occurrence does this type of sample analysis play a key role (Stoffel et al., 2006; Szymczak et al., 2010; KogelnikMayer et al., 2011).

As shown, the entire range of dendrogeomorphological methods and procedures can be used for dating and analysing landslides, flows, avalanches and rockfalls. The current state of the art indicates that the number of studies with sub-annual dating resolution is increasing. This is especially important in matching a given event to its triggering cause. However, further experimental research focused on growth reactions along disturbed trees should be performed to increase the reliability of sub-annual dating. Because every marker of a mass movement event has its own limitations, their combination is recommended. On-going dendrogeomorphological research mainly faces an increasing use of anatomical markers of disturbances and an increasing quantity of analysed samples.

\section{ACKNOWLEDGEMENTS}

This study was realized in the framework of the institutional research program MSM 0021620831 and SVV 265-212. The authors wish to thank Richard J. Robertson for improving the English language.

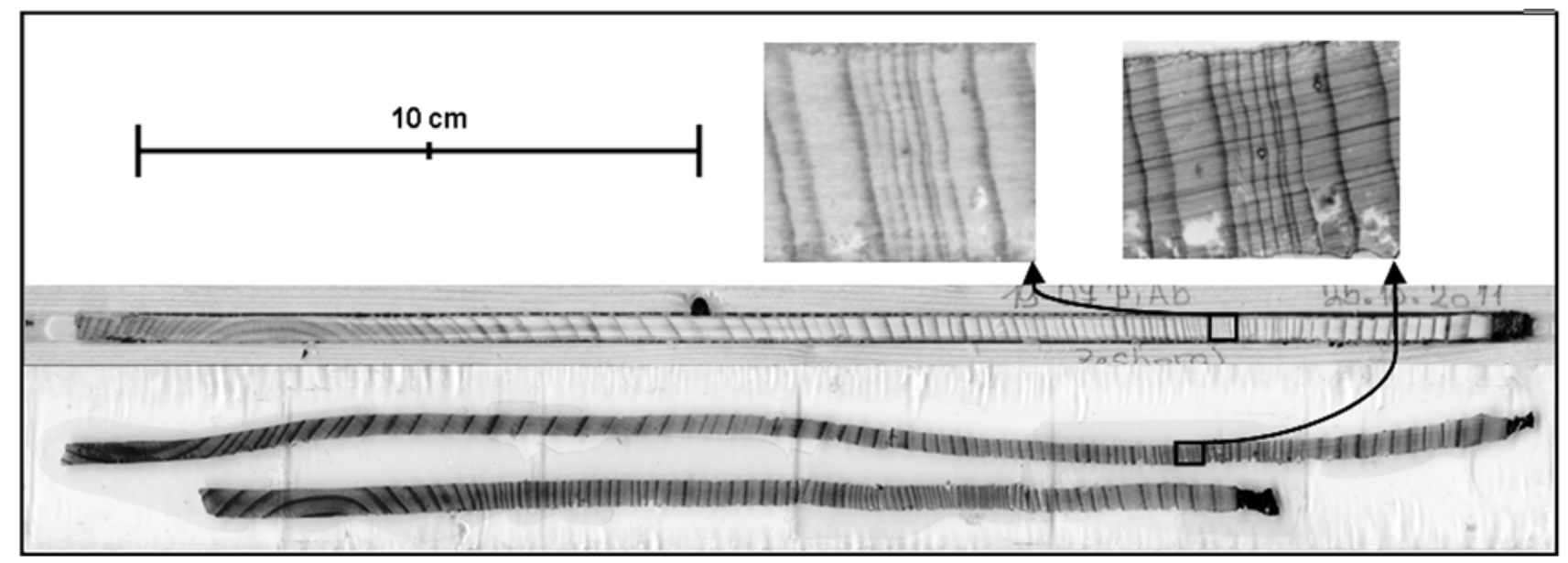

Fig. 5. Long $(\sim 25 \mathrm{~cm})$ and relatively thick microsections $(\sim 50 \mu \mathrm{m})$ enable precise ring-width measurements of gymnosperm wood and semiautomatic analysis of digital images. 


\section{APPENDIX}

Overview of involved studies

\begin{tabular}{|c|c|c|c|c|c|c|c|}
\hline Citation & Locality & $\begin{array}{l}\text { Type of } \\
\text { process }\end{array}$ & Species* & $\begin{array}{l}\text { Sampling } \\
\text { strategy }^{*}\end{array}$ & Growth reactions & Temporal extent & $\begin{array}{l}\text { Temporal } \\
\text { resolution }\end{array}$ \\
\hline $\begin{array}{l}\text { Butler and Malan- } \\
\quad \text { son, } 1985\end{array}$ & $\begin{array}{l}\text { Glacier National } \\
\text { Park, Monatana } \\
\quad \text { (USA) }\end{array}$ & avalanche & $\begin{array}{c}40 \text { Pseudotsuga menziesii } \\
17 \text { Picea engelmanii } \\
11 \text { Pinus contorta } \\
9 \text { Abies lasiocarpa } \\
1 \text { Larix occidentalis } \\
\end{array}$ & $\begin{array}{l}\text { cores, cross- } \\
\text { sections }\end{array}$ & $\begin{array}{l}\text { reaction wood } \\
\text { abrupt growth changes } \\
\text { growth injuries }\end{array}$ & 1924-1985 & year \\
\hline $\begin{array}{l}\text { Hebertson and } \\
\text { Jenkins, } 2003\end{array}$ & $\begin{array}{l}\text { Wasatch plateau } \\
\text { Utah } \\
\text { (USA) }\end{array}$ & avalanche & $261\left\{\begin{array}{l}\text { Picea engelmannii } \\
\text { Abies lasiocarpa }\end{array}\right.$ & $\begin{array}{l}\text { cores, wedge- } \\
\text { cuts }\end{array}$ & $\begin{array}{l}\text { abrupt growth change } \\
\text { reaction wood } \\
\text { growth injuries }\end{array}$ & $1870-1996$ & year \\
\hline Dubé et al., 2004 & $\begin{array}{c}\text { northern Gaspé } \\
\text { peninsula, } \\
\text { Quebec } \\
\text { (Canada) }\end{array}$ & avalanche & $110\left\{\begin{array}{l}\text { Thuya occidentalis } \\
\text { Abies balsamea }\end{array}\right.$ & cross-sections & $\begin{array}{l}\text { growth injuries } \\
\text { reaction wood }\end{array}$ & $1860-1997$ & year \\
\hline \multirow{2}{*}{$\begin{array}{l}\text { Casteller et al., } \\
2007\end{array}$} & $\begin{array}{l}\text { Suchs, canton } \\
\text { Grisons (Switzer- } \\
\text { land) }\end{array}$ & avalanche & $\begin{array}{c}61 \text { Picea abies }(9 \dagger) \\
14 \text { Larix decidua }(5 \dagger) \\
4 \text { Betula pendula }\end{array}$ & $\begin{array}{l}\text { cross-sections, } \\
20 \text { cores }\end{array}$ & \multirow{2}{*}{$\begin{array}{l}\text { average age of trees } \\
\text { reaction wood } \\
\text { eccentricity } \\
\text { growth injuries } \\
\text { TRD } \\
\text { abrupt growth changes }\end{array}$} & \multirow{2}{*}{\begin{tabular}{|c|} 
avalanches \\
confirmed in 1951 \\
and 1977
\end{tabular}} & \multirow{2}{*}{ year } \\
\hline & $\begin{array}{l}\text { Monbiel, canton } \\
\text { Grisons (Switzer- } \\
\text { land) } \\
\end{array}$ & avalanche & $\begin{array}{l}65 \text { Picea abies }(17 \text { †) } \\
1 \text { Larix decidua }\end{array}$ & $\begin{array}{c}\text { cross-sections, } \\
32 \text { cores, } \\
10 \text { wedge-cuts }\end{array}$ & & & \\
\hline $\begin{array}{l}\text { Mundo et al., } \\
\quad 2007\end{array}$ & $\begin{array}{l}\text { valley of Martial, } \\
\text { Tierra del Fuego } \\
\text { (Argentina) }\end{array}$ & avalanche & Nothofagus pumilio & $\begin{array}{c}40 \text { cores, } \\
20 \text { wedge-cuts }\end{array}$ & $\begin{array}{l}\text { growth injuries } \\
\text { abrupt growth changes } \\
\text { eccentricity }\end{array}$ & $\begin{array}{l}\text { avalanche con- } \\
\text { firmed in } 1976\end{array}$ & year \\
\hline $\begin{array}{l}\text { Reardon et al., } \\
2008\end{array}$ & $\begin{array}{c}\text { Glacier National } \\
\text { Park, Montana (USA) }\end{array}$ & avalanche & $109(69 \dagger)^{1}$ & $\begin{array}{l}91 \text { cross- } \\
\text { sections, } \\
64 \text { cores }\end{array}$ & \begin{tabular}{|l|} 
growth injuries \\
reaction wood \\
abrupt growth changes
\end{tabular} & $\begin{array}{l}1936-2003 \\
1910-2003^{2}\end{array}$ & year \\
\hline $\begin{array}{l}\text { Decaulne and } \\
\text { Sæmundsson, } \\
2008\end{array}$ & $\begin{array}{l}\text { valley of Fnjóska- } \\
\text { dalur } \\
\text { (Iceland) }\end{array}$ & avalanche & 10 Betula pubescens & 28 cores & $\begin{array}{l}\text { structure of habit } \\
\text { growth injuries } \\
\text { reaction wood } \\
\end{array}$ & $40 s-2006$ & year \\
\hline $\begin{array}{l}\text { Muntán et al., } \\
\quad 2009\end{array}$ & $\begin{array}{c}6 \text { localities } \\
\text { Catalan Pyrenees } \\
\text { (Spain) }\end{array}$ & avalanche & 448 Pinus uncinata & cores & $\begin{array}{l}\text { abrupt growth changes } \\
\text { reaction wood } \\
\text { growth injuries }\end{array}$ & $\begin{array}{c}1758-2008 \\
\text { (depending on the } \\
\text { locality) }\end{array}$ & year \\
\hline $\begin{array}{l}\text { Casteler et al., } \\
2009\end{array}$ & $\begin{array}{l}\text { Loma del Las Pi- } \\
\text { zaras, Santa Cruz } \\
\quad \text { (Argentina) }\end{array}$ & avalanche & 117 Nothofagus pumilio & $\begin{array}{l}58 \text { cross- } \\
\text { sections, } \\
112 \text { cores, } \\
1 \text { wedge-cut } \\
\end{array}$ & $\begin{array}{l}\text { growth injuries } \\
\text { abrupt growth change } \\
\text { eccentricity } \\
\text { reaction wood }\end{array}$ & $1870-2003$ & year \\
\hline $\begin{array}{l}\text { Laxton and Smith, } \\
2009\end{array}$ & \begin{tabular}{|c|} 
Ratoli, \\
region Lahul, Himálaj \\
(India)
\end{tabular} & avalanche & $36^{3}$ & $\begin{array}{c}\text { cores, } \\
\text { cross-sections }\end{array}$ & $\begin{array}{l}\text { growth injuries } \\
\text { TRD }\end{array}$ & $1972-2005$ & year \\
\hline $\begin{array}{l}\text { Corona et al., } \\
2010\end{array}$ & $\begin{array}{l}\text { Massif de l'Oisans } \\
\text { French Alpes } \\
\text { (France) }\end{array}$ & avalanche & $\begin{array}{l}181 \text { Larix decidua } \\
\text { (about 30\% †) }\end{array}$ & $\begin{array}{l}150 \text { cross- } \\
\text { sections, } \\
328 \text { cores }\end{array}$ & \begin{tabular}{|l|} 
TRD \\
reaction wood \\
callus \\
abrupt growth changes \\
\end{tabular} & $1912-2007$ & year \\
\hline $\begin{array}{l}\text { Germain et al., } \\
2010\end{array}$ & $\begin{array}{c}8 \text { low-elevation paths } \\
12 \text { paths in highlands } \\
\text { Gaspé peninsula, } \\
\text { Quebec } \\
\text { (Canada) } \\
\end{array}$ & avalanche & 1049 not specified & $\begin{array}{l}1592 \text { cross- } \\
\text { sections }\end{array}$ & $\begin{array}{l}\text { growth injuries } \\
\text { reaction wood }\end{array}$ & $\begin{array}{c}1838-2000 \\
\text { (the path with the } \\
\text { longest chronolo- } \\
\text { gy) }\end{array}$ & year \\
\hline $\begin{array}{l}\text { Köse et al., } \\
2010\end{array}$ & $\begin{array}{l}\text { Topçular } \\
\text { Küre-Kastamonu } \\
\text { (Turkey) }\end{array}$ & avalanche & $\begin{array}{l}61 \text { Abies bornmuelleriana } \\
\text { (some of them } \dagger \text { ) }\end{array}$ & 122 cores & $\begin{array}{l}\text { reaction wood } \\
\text { growth injuries } \\
\text { abrupt growth changes } \\
\end{array}$ & $\begin{array}{l}\text { avalanche con- } \\
\text { firmed in } 1992\end{array}$ & year \\
\hline $\begin{array}{l}\text { Garavaglia and } \\
\text { Pelfini } 2011\end{array}$ & $\begin{array}{l}\text { Val Mala } \\
\text { Trentino } \\
\text { (Italy) }\end{array}$ & avalanche & 88 Picea abies (17 †) & $\begin{array}{c}17 \text { cross- } \\
\text { sections, cores }\end{array}$ & $\begin{array}{l}\text { reaction wood } \\
\text { TRD } \\
\text { growth injuries } \\
\text { eccentricity }\end{array}$ & $\begin{array}{l}\text { avalanche con- } \\
\text { firmed in } 2001\end{array}$ & year \\
\hline
\end{tabular}

${ }^{*}$ without trees used for reference chronology building

$\dagger$ deadwood

${ }^{1}$ sampled species aren't specified in the article; Pseudotsuga meziensii dominates in the region with spots of Populus tremuloides, Pinus contorta a

Larix occidentalis

2 combined with historic written records

${ }^{3}$ sampled species aren't specified in the article; Cedrus deodara, Pinus wallichiana, Abies pindrow, Betula utilis a Picea smithiana grow in the locality 


\begin{tabular}{|c|c|c|c|c|c|c|c|}
\hline $\begin{array}{c}\text { Casteller et al., } \\
2011\end{array}$ & $\begin{array}{l}\text { Lago del Desierto } \\
\text { Santa Cruz } \\
\text { (Argentina) }\end{array}$ & avalanche & 95 Nothofagus pumilio & $\begin{array}{l}105 \text { cross- } \\
\text { sections, } \\
3 \text { wedge-cuts }\end{array}$ & $\begin{array}{l}\text { growth injuries } \\
\text { eccentricity } \\
\text { reaction wood } \\
\text { abrupt growth changes }\end{array}$ & $1885-2004$ & year \\
\hline $\begin{array}{l}\text { Corona et al., } \\
2012\end{array}$ & $\begin{array}{c}\text { Arve Valley } \\
\text { Northern French } \\
\text { Alpes } \\
\text { (France) }\end{array}$ & avalanche & $\begin{array}{l}175 \text { Larix decidua } \\
34 \text { Picea abies }\end{array}$ & 452 cores & $\begin{array}{l}\text { abrupt growth change } \\
\text { reaction wood } \\
\text { TRD } \\
\text { growth injuries }\end{array}$ & $1771-2010$ & year \\
\hline $\begin{array}{c}\text { Decaulne et al., } \\
2012\end{array}$ & $\begin{array}{l}\text { valley of Fnjóska- } \\
\text { dalur (Iceland) }\end{array}$ & avalanche & 39 Betula pubescens & $\begin{array}{l}22 \text { cross- } \\
\text { sections, } \\
17 \text { cores }\end{array}$ & $\begin{array}{l}\text { eccentricity } \\
\text { abrupt growth changes }\end{array}$ & $1906-2009$ & year \\
\hline $\begin{array}{l}\text { Stoffel et al., } \\
\quad 2005 \mathrm{~b}\end{array}$ & $\begin{array}{l}\text { Täschgufer } \\
\text { canton Valais } \\
\text { (Switzerland) }\end{array}$ & rockfall & 135 Larix decidua & 564 cores & $\begin{array}{l}\text { TRD } \\
\text { structure of habit } \\
\text { growth injuries } \\
\text { reaction wood } \\
\end{array}$ & $1600-2002$ & \begin{tabular}{|c|} 
decade \\
$(1600-1980)$ \\
year $(1950-$ \\
$2002)$ \\
\end{tabular} \\
\hline $\begin{array}{l}\text { Stoffel et al., } \\
\quad 2005 c\end{array}$ & $\begin{array}{l}\text { Täschguber } \\
\text { canton Valais } \\
\text { (Switzerland) }\end{array}$ & rockfall & 18 Larix decidua & $\begin{array}{l}270 \text { cross- } \\
\text { sections }\end{array}$ & $\begin{array}{l}\text { growth injuries } \\
\text { TRD }\end{array}$ & $1977-2001$ & $\begin{array}{l}\text { part of } \\
\text { growing } \\
\text { season }\end{array}$ \\
\hline $\begin{array}{l}\text { Perret et al., } \\
\quad 2006\end{array}$ & $\begin{array}{l}\text { Diemtigtal, } \\
\text { Bernese Oberland } \\
\text { (Switzerland) }\end{array}$ & rockfall & 33 Picea abies & $\begin{array}{l}33 \text { cross- } \\
\text { sections }\end{array}$ & $\begin{array}{l}\text { growth injuries } \\
\text { TRD }\end{array}$ & $1881-2000$ & \begin{tabular}{|c} 
year \\
part of \\
dendro- \\
chronological \\
year in case \\
of injuries \\
\end{tabular} \\
\hline $\begin{array}{l}\text { Schneuwly and } \\
\text { Stoffel, 2008a }\end{array}$ & $\begin{array}{c}\text { Saas Balen, } \\
\text { canton Valais (Swit- } \\
\text { zerland) }\end{array}$ & rockfall & $\begin{array}{l}176 \text { Larix decidua } \\
14 \text { Picea abies } \\
1 \text { Pinus cembra }\end{array}$ & $\begin{array}{l}796 \text { cores, } \\
141 \text { cross- } \\
\text { sections }\end{array}$ & $\begin{array}{l}\text { TRD } \\
\text { growth injuries } \\
\text { abrupt growth changes } \\
\text { callus } \\
\text { reaction wood } \\
\end{array}$ & $1957-2006$ & year \\
\hline $\begin{array}{l}\text { Schneuwly and } \\
\text { Stoffel, 2008b }\end{array}$ & $\begin{array}{l}\text { Saas Balen } \\
\text { canton Valais } \\
\text { (Switzerland) }\end{array}$ & rockfall & $\begin{array}{l}23 \text { Larix decidua } \\
8 \text { Picea abies } \\
1 \text { Pinus cembra }\end{array}$ & $\begin{array}{l}123 \text { cross- } \\
\text { sections }\end{array}$ & $\begin{array}{l}\text { growth injuries } \\
\text { TRD }\end{array}$ & $1975-2006$ & $\begin{array}{l}\text { part of } \\
\text { growing } \\
\text { season }\end{array}$ \\
\hline $\begin{array}{l}\text { Migoń et al., } \\
2010\end{array}$ & $\begin{array}{c}\text { Włostova-Suchawa, } \\
\text { Kamienne hory } \\
\text { (Poland) } \\
\end{array}$ & rockfall & 32 Picea abies & $\begin{array}{l}32 \text { cross- } \\
\text { sections, } \\
30 \text { cores }\end{array}$ & \begin{tabular}{|l|} 
growth injuries \\
reaction wood \\
TRD \\
\end{tabular} & $1859-2007$ & year \\
\hline $\begin{array}{l}\text { Moya et al., } \\
2010\end{array}$ & $\begin{array}{l}\text { Solà d'Andorra } \\
\text { (Andorra) }\end{array}$ & rockfall & $\begin{array}{l}227 \text { Quercus robur } \\
49 \text { Quercus ilex } 4\end{array}$ & $\begin{array}{l}\text { cross-sections, } \\
\text { wedge-cuts }\end{array}$ & growth injuries & $1959-2001$ & $\begin{array}{c}\text { part of } \\
\text { dendro- } \\
\text { chronological } \\
\text { year }\end{array}$ \\
\hline $\begin{array}{l}\text { Šihán, } \\
\text { 2010a }\end{array}$ & $\begin{array}{c}\text { Smrk, } \\
\text { Moravskoslezské } \\
\text { Beskydy Mts. } \\
\end{array}$ & rockfall & $\begin{array}{c}39 \text { Acer pseudoplatanus } \\
12 \text { Picea abies } \\
6 \text { Fagus sylvatica }\end{array}$ & 168 cores & \begin{tabular}{|l|} 
growth injuries \\
abrupt growth changes \\
TRD \\
\end{tabular} & $1951-2008$ & year \\
\hline \multirow{2}{*}{ Šilhán, 2011} & $\begin{array}{l}\text { Lysá Hora, } \\
\text { Moravskoslezské } \\
\text { Beskydy Mts. }\end{array}$ & rockfall & $\begin{array}{c}35 \text { Ulmus glabra } \\
11 \text { Fagus sylvatica } \\
9 \text { Acer pseudoplatanus } \\
3 \text { Picea abies }\end{array}$ & \multirow{2}{*}{ cores } & \multirow{2}{*}{$\begin{array}{l}\text { abrupt growth change } \\
\text { TRD } \\
\text { reaction wood } \\
\text { growth injuries }\end{array}$} & $1905-2011$ & \multirow{2}{*}{$\begin{array}{l}\text { temporal and } \\
\text { spatial } \\
\text { variation of } \\
\text { event fre- } \\
\text { quency }\end{array}$} \\
\hline & $\begin{array}{l}\text { Ropice, } \\
\text { Moravskoslezské } \\
\text { Beskydy Mts. }\end{array}$ & rockfall & $\begin{array}{c}106 \text { Picea abies } \\
4 \text { Acer pseudoplatanus } \\
4 \text { Fagus sylvatica } \\
\text { 1 Sorbus aucuparia } \\
\end{array}$ & & & $1899-2011$ & \\
\hline Stoffel et al., 2011 & \begin{tabular}{|c|} 
Rodadero, \\
Iztaccíhuatl volcano \\
(Mexico) \\
\end{tabular} & rockfall & 24 Pinus hartweigii & $\begin{array}{l}4 \text { cross- } \\
\text { sections, } \\
82 \text { cores }\end{array}$ & $\begin{array}{l}\text { abrupt growth change } \\
\text { growth injuries } \\
\text { reaction wood }\end{array}$ & $1924-2008$ & year \\
\hline $\begin{array}{c}\text { Yoshida et al., } \\
1997\end{array}$ & $\begin{array}{l}\text { Ochiushinai, } \\
\text { Rishiri island } \\
\text { (Japan) }\end{array}$ & flow & $\begin{array}{c}6 \text { Abies sachalinensis } \\
\text { (all } \dagger \text { ) }\end{array}$ & cross-sections & $\begin{array}{l}\text { year of germination } \\
\text { year of death }\end{array}$ & $1849-1979$ & decade \\
\hline $\begin{array}{c}\text { Baumann and } \\
\text { Kaiser, } 1999\end{array}$ & $\begin{array}{c}\text { Multetta, } \\
\text { Val Müstair } \\
\text { (Switzerland) }\end{array}$ & flow & $\begin{array}{c}57 \text { Pinus mugo } \\
(6+)\end{array}$ & $\begin{array}{l}\text { cores, } \\
\text { cross-sections }\end{array}$ & $\begin{array}{l}\text { abrupt growth changes } \\
\text { growth injuries } \\
\text { adventitious roots } \\
\end{array}$ & $\begin{array}{c}\text { beggining of } 16^{\text {th }} \\
\text { century - } \\
1990 \\
\end{array}$ & year \\
\hline $\begin{array}{l}\text { Santilli and Pelfini, } \\
2002\end{array}$ & $\begin{array}{c}\text { Valle della Casina, } \\
\text { Lombrady } \\
\text { (Italy) }\end{array}$ & flow & 53 Pinus montana $(1 \dagger)$ & $\begin{array}{c}\text { cores, } \\
\text { cross-sections }\end{array}$ & $\begin{array}{l}\text { reaction wood } \\
\text { growth injuries }\end{array}$ & $1837-1998$ & $\begin{array}{l}\text { year }-5 \\
\text { years }\end{array}$ \\
\hline $\begin{array}{l}\text { Wilkerson and } \\
\text { Schmid, } 2003\end{array}$ & $\begin{array}{c}\text { Glacier National Park } \\
\text { Montana } \\
\text { (USA) }\end{array}$ & flow & $?$ & $\begin{array}{l}40 \text { cores, } \\
13 \text { cross- } \\
\text { sections }\end{array}$ & year of germination & $1857-2000$ & $\begin{array}{c}\text { minimum age } \\
\text { estimation }\end{array}$ \\
\hline $\begin{array}{c}\text { May and } \\
\text { Gresswell, } 2004\end{array}$ & $\begin{array}{c}\text { Oregon Coast Range } \\
\text { (USA) }\end{array}$ & flow & $\begin{array}{c}\text { Pseudotsuga menziesii } \\
\text { Tsuga heterophylla }\end{array}$ & cores & year of germination & $>90$ years & $\begin{array}{l}\text { minimum age } \\
\text { estimation }\end{array}$ \\
\hline
\end{tabular}

${ }^{4}$ only 22 individuals of Quercus ilex were finaly used for the analysis, because of very frequent presence of false-rings (evergreen species) 


\begin{tabular}{|c|c|c|c|c|c|c|c|}
\hline $\begin{array}{l}\text { Stoffel et al., } \\
\text { 2005a }\end{array}$ & $\begin{array}{c}\text { Ritigraben, } \\
\text { canton Valais } \\
\text { (Switzerland) }\end{array}$ & flow & $>1200\left\{\begin{array}{l}\text { Larix decidua } \\
\text { Picea abies } \\
\text { Pinus cembra }\end{array}\right.$ & 2450 cores & $\begin{array}{l}\text { reaction wood } \\
\text { abrupt growth changes } \\
\text { TRD }\end{array}$ & $1605-2002$ & year \\
\hline \multirow{2}{*}{$\begin{array}{l}\text { Bollschweiler and } \\
\text { Stoffel, } 2007\end{array}$} & $\begin{array}{c}\text { Reuse de Saleinaz, } \\
\text { canton Valais } \\
\text { (Switzerland) }\end{array}$ & flow & $\begin{array}{l}148 \text { Larix decidua } \\
49 \text { Pinus sylvestris } \\
31 \text { Picea abies }\end{array}$ & \multirow{2}{*}{ cores } & \multirow{2}{*}{$\begin{array}{l}\text { TRD } \\
\text { abrupt growth changes } \\
\text { reaction wood } \\
\text { growth injuries }\end{array}$} & \multirow{2}{*}{$\begin{array}{l}1743-2003 \\
1862-2003\end{array}$} & \multirow{2}{*}{ year } \\
\hline & $\begin{array}{c}\text { La Fouly, } \\
\text { canton Valais } \\
\text { (Switzerland) }\end{array}$ & flow & $\begin{array}{l}42 \text { Picea abies } \\
8 \text { Larix decidua }\end{array}$ & & & & \\
\hline $\begin{array}{l}\text { Bollschweiller } \\
\text { et al., } 2007\end{array}$ & $\begin{array}{l}\text { Blatten b. Naters, } \\
\text { canton Valais (Swit- } \\
\text { zerland) }\end{array}$ & flow & $401\left\{\begin{array}{l}\text { Picea abies } \\
\text { Larix decidua }\end{array}\right.$ & 802 cores & \begin{tabular}{|l|} 
TRD \\
reaction wood \\
abrupt growth changes \\
growth injuries \\
\end{tabular} & $1867-2005$ & year \\
\hline $\begin{array}{l}\text { Pelfini and Santilli, } \\
2008\end{array}$ & $\begin{array}{l}\text { Valle del Galo } \\
\text { Lombardy } \\
\text { (Italy) }\end{array}$ & flow & 757 Pinus montana & $\begin{array}{c}\text { cores, } \\
\text { cross-sections }\end{array}$ & $\begin{array}{l}\text { abrupt growth change } \\
\text { growth injuries } \\
\text { reaction wood }\end{array}$ & $1875-2003$ & $\begin{array}{c}\text { year } \\
\text { part of the } \\
\text { year in some } \\
\text { cases }\end{array}$ \\
\hline $\begin{array}{l}\text { Bollschweiller } \\
\text { et al., } 2008\end{array}$ & $\begin{array}{l}\text { Grosse Grabe, } \\
\text { canton Valais } \\
\text { (Switzerland) }\end{array}$ & flow & $261\left\{\begin{array}{l}\text { Larix decidua } \\
\text { Picea abies }\end{array}\right.$ & 222 cores & \begin{tabular}{|l|} 
year of germination \\
TRD \\
reaction wood \\
abrupt growth changes \\
growth injuries \\
\end{tabular} & $1782-2005$ & year \\
\hline $\begin{array}{l}\text { Šilhán and Pánek, } \\
2008\end{array}$ & $\begin{array}{l}\text { Travný, Ostrý, Smrk, } \\
\text { Moravskoslezské } \\
\text { Beskydy Mts. } \\
\text { (Czech Republic) }\end{array}$ & flow & $\begin{array}{c}\text { Picea abies } \\
\text { Fagus sylvatica } \\
\text { Alnus glutinosa }\end{array}$ & $\begin{array}{l}52 \text { cores, } \\
21 \text { cross- } \\
\text { sections }\end{array}$ & $\begin{array}{l}\text { abrupt growth changes } \\
\text { growth injuries }\end{array}$ & $1939-2002$ & year \\
\hline $\begin{array}{l}\text { Stoffel and } \\
\text { Bolschweiler, } \\
\text { 2009b }\end{array}$ & $\begin{array}{c}\text { Péterey } \\
\text { canton Valais (Swit- } \\
\text { zerland) }\end{array}$ & flow & 35 Larix decidua & 70 cores & \begin{tabular}{|l|} 
TRD \\
growth injuries \\
reaction wood \\
abrupt growth changes
\end{tabular} & $1862-2007$ & year \\
\hline Sorg et al., 2010 & $\begin{array}{c}\text { Geisstriftbach, } \\
\text { canton Valais (Swit- } \\
\text { zerland) }\end{array}$ & flow & $\begin{array}{l}26 \text { Larix decidua } \\
2 \text { Picea abies }\end{array}$ & $\begin{array}{c}54 \text { cores, } \\
7 \text { cross-sections }\end{array}$ & $\begin{array}{l}\text { year of germination } \\
\text { growth injuries } \\
\text { exposed tree roots } \\
\text { decapitation } \\
\text { TRD } \\
\text { reaction wood } \\
\text { abrupt growth changes } \\
\end{array}$ & $1913-2006$ & year \\
\hline $\begin{array}{l}\text { Arbellay et al., } \\
2010\end{array}$ & $\begin{array}{c}\text { Illgraben } \\
\text { canton Valais } \\
\text { (Switzerland) }\end{array}$ & flow & $\begin{array}{l}80 \text { Alnus incana } \\
29 \text { Populus sp. } \\
28 \text { Betula sp. } \\
15 \text { Salix caprea } \\
2 \text { Sambucus nigra }\end{array}$ & $\begin{array}{l}104 \text { cores, } \\
118 \text { wedge- } \\
\text { cuts, } \\
93 \text { cross- } \\
\text { section } \\
\end{array}$ & $\begin{array}{l}\text { growth injuries } \\
\text { abrupt growth changes }\end{array}$ & $1917-2008$ & $\begin{array}{l}\text { part of } \\
\text { growing } \\
\text { season }\end{array}$ \\
\hline $\begin{array}{l}\text { Bollschweiler and } \\
\text { Stoffel, } \\
2010\end{array}$ & $\begin{array}{l}\text { Birchbach, } \\
\text { canton Valais } \\
\text { (Switzerland) }\end{array}$ & flow & $\begin{array}{l}201 \text { Larix decidua } \\
9 \text { Picea abies }\end{array}$ & cores & \begin{tabular}{|l|} 
TRD \\
growth injuries \\
reaction wood \\
abrupt growth changes
\end{tabular} & $1752-2006$ & year \\
\hline Owczarek, 2010 & $\begin{array}{l}\text { Wedel Jarlsberg } \\
\text { Land, Svalbard } \\
\text { (Norway) }\end{array}$ & flow & $\begin{array}{l}\text { Salix reticulata } \\
\text { Salix polaris }\end{array}$ & cross-sections & $\begin{array}{l}\text { reaction wood } \\
\text { year of germination } \\
\text { growth injuries }\end{array}$ & $1955-2010$ & year \\
\hline $\begin{array}{l}\text { Šilhán, } \\
\text { 2010b }\end{array}$ & $\begin{array}{c}\text { Slavíč, } \\
\text { Moravskoslezské } \\
\text { Beskydy Mts. } \\
\text { (Czech Republic) }\end{array}$ & flow & 6 Picea abies $(1 \dagger)$ & $\begin{array}{l}3 \text { cross- } \\
\text { sections, } \\
3 \text { cores }\end{array}$ & $\begin{array}{l}\text { abrupt growth changes } \\
\text { growth injuries on roots }\end{array}$ & $\begin{array}{c}\text { debris-flows } \\
\text { confirmed in } 1972 \\
\text { and } 1997\end{array}$ & year \\
\hline $\begin{array}{l}\text { Procter et al., } \\
\quad 2011\end{array}$ & $\begin{array}{l}\text { Gamperdonatal, } \\
\text { Voralberg } \\
\text { (Austria) }\end{array}$ & flow & $\begin{array}{c}268 \text { Pinus mugo ssp. } \\
\text { uncinata } \\
164 \text { Picea abies } \\
10 \text { Abies alba } \\
\text { (some †) }\end{array}$ & \begin{tabular}{|c|}
779 cores, \\
69 cross- \\
sections, \\
2 wedge-cuts, \\
4 root samples \\
\end{tabular} & $\begin{array}{l}\text { abrupt growth change } \\
\text { TRD } \\
\text { growth injuries } \\
\text { reaction wood }\end{array}$ & $1839-2010$ & year \\
\hline $\begin{array}{l}\text { Mayer et al., } \\
2010\end{array}$ & $\begin{array}{c}\text { Gratzental, } \\
\text { Tyrol } \\
\text { (Austria) }\end{array}$ & $\begin{array}{l}\text { "debris- } \\
\text { flood" }\end{array}$ & $\begin{array}{l}224 \text { Picea abies } \\
3 \text { Larix decidua }\end{array}$ & $\begin{array}{l}490 \text { cores, } \\
10 \text { cross- } \\
\text { sections }\end{array}$ & \begin{tabular}{|l|} 
abrupt growth changes \\
TRD \\
reaction wood \\
growth injuries
\end{tabular} & $1800-2008$ & year \\
\hline $\begin{array}{l}\text { Bollschweiler } \\
\text { et al., } 2011\end{array}$ & $\begin{array}{l}\text { torrent de la Greffe } \\
\text { canton Valais (Swit- } \\
\text { zerland) }\end{array}$ & "debris- & $\begin{array}{c}44 \text { Picea abies } \\
55 \text { angiosperms }\end{array}$ & \begin{tabular}{|c|}
159 cores, \\
31 wedge-cuts, \\
16 cross- \\
sections
\end{tabular} & $\begin{array}{l}\text { TRD } \\
\text { abrupt growth changes } \\
\text { reaction wood } \\
\text { growth injuries }\end{array}$ & $1900-2007$ & year \\
\hline
\end{tabular}

${ }^{5}$ Fraxinus excelsior, Fagus sylvatica, Acer sp., Ulmus glabra, Robinia pseudoacacia, Viburnum lantana, Salix caprea, Alnus incana, Populus tremula, Sorbus aria 


\begin{tabular}{|c|c|c|c|c|c|c|c|}
\hline $\begin{array}{l}\text { Bollschweiler } \\
\text { et al., } 2010\end{array}$ & $\begin{array}{l}\text { Popocatépetl } \\
\text { (Mexico) }\end{array}$ & lahar & $\begin{array}{l}22 \text { Pinus hartwegii } \\
21 \text { Abies religiosa } \\
19 \text { Pinus ayacahuite }\end{array}$ & $\begin{array}{c}137 \text { cores, } \\
3 \text { cross-sections }\end{array}$ & $\begin{array}{l}\text { abrupt growth changes } \\
\text { TRD } \\
\text { growth injuries } \\
\text { reaction wood } \\
\end{array}$ & $1795-2008$ & year \\
\hline \multirow{2}{*}{$\begin{array}{l}\text { Corominas and } \\
\text { Moya, } 2010\end{array}$} & $\begin{array}{l}\text { Tordó torrent, } \\
\text { Eastern Pyrenees } \\
\text { (Spain) }\end{array}$ & flow & 196 Pinus sylvestris & $\begin{array}{l}\text { wedge-cuts, } \\
\text { cross-sections, } \\
\text { cores }\end{array}$ & $\begin{array}{l}\text { year of germination } \\
\text { growth injuries } \\
\text { abrupt growth changes } \\
\text { reaction wood }\end{array}$ & $1949-2000$ & year \\
\hline & $\begin{array}{c}\text { Clot d'Esquers, } \\
\text { Eastern Pyrenees } \\
\text { (Spain) }\end{array}$ & landslide & 49 Pinus sylvestris & $?$ (cores) & \begin{tabular}{|l|} 
reaction wood \\
eccentricity \\
year of germination
\end{tabular} & $1932-1993$ & year \\
\hline $\begin{array}{l}\text { Corominas and } \\
\text { Moya, } 1999\end{array}$ & $\begin{array}{l}\text { basin of Llobregat r., } \\
\text { Pyrenees } \\
\text { (Spain) }\end{array}$ & $\begin{array}{l}\text { landslide } \\
\text { local flows }\end{array}$ & 250 not specified & cores & \begin{tabular}{|l|} 
eccentricity \\
growth injuries \\
reaction wood
\end{tabular} & 1926-1995 & year \\
\hline $\begin{array}{c}\text { Fantucci and } \\
\text { Sorriso-Valvo, } \\
1999 \\
\end{array}$ & $\begin{array}{l}\text { Greci, } \\
\text { Calabria } \\
\text { (Italy) }\end{array}$ & $\begin{array}{l}\text { landslide } \\
\text { local flows }\end{array}$ & 24 Quercus pubescens & cores & $\begin{array}{l}\text { abrupt growth changes } \\
\text { bending of the stem }\end{array}$ & $1820-1994$ & year \\
\hline Gers et al., 2001 & $\begin{array}{c}\text { NW Rheinhessen } \\
\text { (Germany) }\end{array}$ & landslide & 28 Crataegus oxyacantha & cores & $\begin{array}{l}\text { abrupt growth change } \\
\text { reaction wood }\end{array}$ & $1970-1997$ & year \\
\hline Grau et al., 2003 & $\begin{array}{l}\text { Northwestern sub- } \\
\text { tropical Argentina }\end{array}$ & landslide & 22 Alnus acuminata & cores & $\begin{array}{l}\text { abrupt growth change } \\
\text { year of germination }\end{array}$ & $\begin{array}{l}\text { landslide con- } \\
\text { firmed in } 1983\end{array}$ & year \\
\hline \multirow{3}{*}{$\begin{array}{l}\text { Carrara and } \\
\text { O'Neill, } \\
2003\end{array}$} & $\begin{array}{l}\text { Bench road } \\
\text { Gravelly range, } \\
\text { Montana (USA) }\end{array}$ & landslide & $\begin{array}{l}11 \text { Pseudotsuga menziesii } \\
(1 \dagger)\end{array}$ & $\begin{array}{l}7 \text { cross- } \\
\text { sections, } \\
4 \text { cores }\end{array}$ & \multirow{3}{*}{$\begin{array}{l}\text { abrupt growth changes } \\
\text { reaction wood } \\
\text { growth injuries }\end{array}$} & \multirow{3}{*}{$1855-1993(5)$} & \multirow{3}{*}{ year } \\
\hline & $\begin{array}{c}\text { Cliff lake } \\
\text { Gravelly range, } \\
\text { Montana (USA) }\end{array}$ & landslide & $\begin{array}{l}10 \text { Pseudotsuga menziesii } \\
(1 \dagger)\end{array}$ & $\begin{array}{l}9 \text { cross- } \\
\text { sections, } \\
1 \text { core } \\
\end{array}$ & & & \\
\hline & $\begin{array}{l}\text { Freezeout lake } \\
\text { Gravelly range, } \\
\text { Montana (USA) }\end{array}$ & landslide & $\begin{array}{c}7 \text { Pseudotsuga menziesii } \\
2 \text { Pinus contorta } \\
1 \text { Abies lasiocarpa } \\
1 \text { Pinus flexilis } \\
\end{array}$ & $\begin{array}{l}9 \text { cross- } \\
\text { sections, } \\
2 \text { cores }\end{array}$ & & & \\
\hline $\begin{array}{l}\text { Stefanini, } \\
2004\end{array}$ & $\begin{array}{l}\text { Secchio, } \\
\text { Emilia-Romagna } \\
\text { (Italy) }\end{array}$ & landslide & 24 Quercus cerris & 48 cores & abrupt growth changes & $1920-2001$ & $\begin{array}{l}\text { part of } \\
\text { growing } \\
\text { season }\end{array}$ \\
\hline $\begin{array}{l}\text { Paolini et al., } \\
\quad 2005\end{array}$ & $\begin{array}{l}3 \text { localities } \\
\text { provinces Tucu- } \\
\text { mán,Jujuy } \\
\text { (Argentina) }\end{array}$ & landslide & Alnus acuminata & $\begin{array}{c}\text { cores, } \\
\text { cross-sections }\end{array}$ & $\begin{array}{l}\text { year of germination } \\
\text { abrupt growth changes }\end{array}$ & $1935-2002$ & year \\
\hline $\begin{array}{l}\text { Wieczorek et al., } \\
2006\end{array}$ & $\begin{array}{l}\text { Meadow Run } \\
\text { Virginia } \\
\text { (USA) }\end{array}$ & landslide & $\begin{array}{l}3 \text { Sassafras albidum } \\
2 \text { Quercus rubra } \\
2 \text { Pinus virginiana } \\
1 \text { Quercus alba } \\
1 \text { Nyssa sylvatica } \\
1 \text { Kalmia latifolia } \\
\end{array}$ & $\begin{array}{c}\text { cores, } \\
\text { cross-sections }\end{array}$ & $\begin{array}{l}\text { year of germination } \\
\text { dating of adventitious } \\
\text { sprouts } \\
\text { abrupt growth changes } \\
\text { eccentricity }\end{array}$ & $1850-2002$ & year \\
\hline $\begin{array}{l}\text { Guida et al., } \\
\quad 2008\end{array}$ & $\begin{array}{l}\text { Monte Sirino } \\
\text { Calabria } \\
\text { (Italy) }\end{array}$ & landslide & $54\left\{\begin{array}{l}\text { Quercus cerris } \\
\text { Alnus cordata } \\
\text { Castanea sativa }^{f} \\
\text { Juglans regia } \\
\text { Populus canadensis } 6 \\
\text { Robinia pseudoacacia }\end{array}\right.$ & cores & $\begin{array}{l}\text { abrupt growth changes } \\
\text { eccentricity }\end{array}$ & $1959-2004$ & year \\
\hline $\begin{array}{l}\text { Van Den Eeckhaut } \\
\text { et al., } 2009\end{array}$ & $\begin{array}{c}\text { Koppenbrg, } \\
\text { Flemish Ardennes } \\
\text { (Belgium) }\end{array}$ & landslide & $\begin{array}{l}147 \text { Fagus sylvatica } \\
\text { (samples only from 19) }\end{array}$ & $\begin{array}{l}\text { habit analysis } \\
13 \text { cross- } \\
\text { sections, } \\
32 \text { cores }\end{array}$ & $\begin{array}{l}\text { structure of habit } \\
\text { eccentricity } \\
\text { abrupt growth changes }\end{array}$ & $1910-1999$ & year \\
\hline $\begin{array}{l}\text { Bégin and Filion, } \\
2010\end{array}$ & $\begin{array}{c}\text { Poste-de-la-Baleine, } \\
\text { Qubec } \\
\text { (Canada) }\end{array}$ & landslide & $\begin{array}{c}363 \text { Picea glauca } \\
\text { (303 only for minimal age } \\
\text { estimation) }\end{array}$ & $\begin{array}{l}\text { cross-sections, } \\
\text { cores (for } \\
\text { minimal age } \\
\text { estimation) } \\
\end{array}$ & $\begin{array}{l}\text { abrupt growth changes } \\
\text { reaction wood } \\
\text { year of germination }\end{array}$ & $\begin{array}{l}\text { landslides con- } \\
\text { firmed in } 1818, \\
1839 \text { and } 1846\end{array}$ & $\begin{array}{l}\text { part of } \\
\text { growing } \\
\text { season }\end{array}$ \\
\hline Bollati et al., 2012 & $\begin{array}{c}\text { Ombrone river basin } \\
\text { (Italy) }\end{array}$ & landslide & 45 Pinus pinea & $\begin{array}{c}\text { cores, } \\
\text { cross-sections }\end{array}$ & $\begin{array}{l}\text { abrupt growth changes } \\
\text { reaction wood }\end{array}$ & $1990-2009$ & year \\
\hline $\begin{array}{l}\text { Lopez Saez et al., } \\
\text { 2012a }\end{array}$ & $\begin{array}{c}\text { Bois Noir, Barce- } \\
\text { lonnette Basin } \\
\text { (France) }\end{array}$ & landslide & 79 Pinus uncinata & $\begin{array}{c}300 \text { cores, } \\
4 \text { cross-sections }\end{array}$ & $\begin{array}{l}\text { reaction wood } \\
\text { abrupt growth change }\end{array}$ & $1874-2009$ & $\begin{array}{l}\text { part of } \\
\text { growing } \\
\text { season } \\
\end{array}$ \\
\hline $\begin{array}{l}\text { Lopez Saez et al., } \\
\text { 2012b }\end{array}$ & $\begin{array}{c}\text { Aiguettes landslide, } \\
\text { Ubaye valley, south- } \\
\text { ern French Alps } \\
\text { (France) }\end{array}$ & landslide & 223 Pinus uncinata & 892 cores & $\begin{array}{l}\text { age structure } \\
\text { abrupt growth change } \\
\text { reaction wood } \\
\text { growth injuries }\end{array}$ & $1890-2011$ & $\begin{array}{l}\text { year } \\
\text { part of } \\
\text { growing } \\
\text { season } \\
\end{array}$ \\
\hline
\end{tabular}

6 these species have been found useless for dendrogeomorphological purpouses and they were excluded out of the analysis; finally, samples only from 34 trees were evaluated 


\begin{tabular}{|c|c|c|c|c|c|c|c|}
\hline $\begin{array}{l}\text { Lopez Saez et al., } \\
\text { 2012c }\end{array}$ & $\begin{array}{c}\text { Pra Bellon landslide } \\
\text { Ubaye valley, } \\
\text { southern French Alps } \\
\text { (France) }\end{array}$ & landslide & 403 Pinus uncinata & 1563 cores & $\begin{array}{l}\text { year of germination } \\
\text { abrupt growth change } \\
\text { reaction wood } \\
\text { growth injuries }\end{array}$ & 1848-2011 & year \\
\hline $\begin{array}{l}\text { Van der Burght } \\
\text { et al., } 2012\end{array}$ & $\begin{array}{l}\text { Grossgufer } \\
\text { canton Valais } \\
\text { (Switzerland) }\end{array}$ & rockslide & $\begin{array}{c}269 \text { Larix decidua } \\
\text { (1792 budscale-counting) } \\
45 \text { Picea abies } \\
39 \text { Betula pendula }\end{array}$ & $\begin{array}{l}\text { cross-sections } \\
\text { counting } \\
\text { budscale scars }\end{array}$ & year of germination & $\begin{array}{l}\text { confirmed origin } \\
\text { of talus in } 1991\end{array}$ & $\begin{array}{l}\text { minimum age } \\
\text { estimation }\end{array}$ \\
\hline $\begin{array}{l}\text { Stoffel et al., } \\
\quad 2006\end{array}$ & $\begin{array}{l}\text { Birchbach, } \\
\text { canton Valais } \\
\text { (Switzerland) }\end{array}$ & $\begin{array}{l}\text { avalanche } \\
\text { and flow }\end{array}$ & $251\left\{\begin{array}{l}\text { Larix decidua } \\
\text { Picea abies }\end{array}\right.$ & 520 cores & $\begin{array}{l}\text { TRD } \\
\text { reaction wood } \\
\text { abrupt growth changes } \\
\text { growth injuries } \\
\end{array}$ & $1750-2002$ & $\begin{array}{l}\text { part of } \\
\text { growing } \\
\text { season }\end{array}$ \\
\hline $\begin{array}{l}\text { Malik and } \\
\text { Owczarek, } \\
2009\end{array}$ & $\begin{array}{l}\text { Červená hora } \\
\text { Hrubý Jeseník } \\
\text { (Czech Republic) }\end{array}$ & $\begin{array}{l}\text { avalanche } \\
\text { and flow } \\
\text { (not distin- } \\
\text { guished) }\end{array}$ & $\begin{array}{l}20 \text { Picea abies } \\
8 \text { Fagus sylvatica } \\
16 \text { not specified } \dagger\end{array}$ & $\begin{array}{c}\text { cores, } \\
\text { cross-sections }\end{array}$ & $\begin{array}{l}\text { abrupt growth changes } \\
\text { year of death }\end{array}$ & $1912-2004$ & year \\
\hline $\begin{array}{l}\text { Szymczak et al., } \\
2010\end{array}$ & $\begin{array}{l}\text { Meretschibach, } \\
\text { canton Valais } \\
\text { (Switzerland) }\end{array}$ & $\begin{array}{l}\text { avalanche } \\
\text { and flow }\end{array}$ & $\begin{array}{c}57 \text { Picea abies } \\
12 \text { Alnus incana } \\
9 \text { Sorbus aucuparia } \\
4 \text { Betula pubescens } \\
2 \text { Larix decidua } \\
9 \text { others }^{7} \\
\end{array}$ & $\begin{array}{l}171 \text { cores, } \\
34 \text { wedge-cuts, } \\
11 \text { cross- } \\
\text { sections }\end{array}$ & $\begin{array}{l}\text { TRD } \\
\text { abrupt growth changes } \\
\text { reaction wood } \\
\text { growth injuries }\end{array}$ & $1930-2008$ & $\begin{array}{l}\text { part of } \\
\text { growing } \\
\text { season }\end{array}$ \\
\hline $\begin{array}{l}\text { Kogelnik-Mayer } \\
\text { et al., } 2011\end{array}$ & $\begin{array}{c}\text { Reiselehnrinne, } \\
\text { Tyrol } \\
\text { (Austria) }\end{array}$ & $\begin{array}{l}\text { avalanche } \\
\text { and flow }\end{array}$ & 372 Picea abies & $\begin{array}{l}731 \text { cores, } \\
41 \text { cross- } \\
\text { sections }\end{array}$ & $\begin{array}{l}\text { abrupt growth changes } \\
\text { reaction wood } \\
\text { TRD } \\
\text { growth injuries }\end{array}$ & $1821-2009$ & $\begin{array}{l}\text { part of } \\
\text { growing } \\
\text { season }\end{array}$ \\
\hline
\end{tabular}

${ }^{7} 2$ Abies alba, 2 Acer pseudoplatanus, Laburnum alpinum, Corylus colurna, Ulmus glabra, Fraxinus excelsior, Buddleja daviddi

\section{REFERENCES}

Alestalo J, 1971. Dendrochronological interpretation of geomorphological processes. Fennia 105: 1-139.

Arbellay E, Stoffel M and Bollschweiler M, 2010. Dendrogeomorphic reconstruction of past debris-flow activity using injured broadleaved trees. Earth Surface Processes and Landforms 35(4): 399406, DOI 10.1002/esp.1934.

Baumann F and Kaiser KF, 1999. The Multetta Debris Fan, Eastern Swiss Alps: A 500-year Debris Flow Chronology. Arctic, Antarctic and Alpine Research 31(2): 128-134, DOI 10.2307/1552601.

Bégin Ch and Filion L, 2010. Age of Landslides Along the Grande Riviére de la Baleine Estuary, Eastern Coast of Hudson Bay, Quebec (Canada). In: Stoffel M, Bollschweiler M, Butler DR and Luckman BH, eds, Tree Rings and Natural Hazards. Advances in Global Change Research 41. Springer, Dordrecht Heidelberg London New York: 107-120.

Bodoque JM, Díez-Herrero A, Martín-Duque JF, Rubiales JM, Godfrey A, Pedraza J, Carrasco RM and Sanz MA, 2005. Sheet erosion rates determined by using dendrogeomorphological analysis of exposed tree roots: Two examples from Central Spain. Catena 64(1): 81-102, DOI 10.1016/j.catena.2005.08.002.

Bollati I, Della Seta M, Pelfini M, Del Monte M, Fredi P and Lupia Palmieri E, 2012. Dendrochronological and geomorphological investigations to assess water erosion and mass wasting processes in the Apennines of Southern Tuscany (Italy). Catena 90: 1-17, DOI 10.1016/j.catena.2011.11.005.

Bollschweiler M and Stoffel M, 2007. Debris flows on forested cones reconstruction and comparison of frequencies in two catchments in Val Ferret, Switzerland. Natural Hazards and Earth System Sciences 7(2): 207-218, DOI 10.5194/nhess-7-207-2007.

Bollschweiler M and Stoffel M, 2010. Variations in debris-flow occurence in an Alpine catchment - A reconstuction based on tree rings. Global and Planetary Change 73(3-4): 186-192, DOI 10.1016/j.gloplacha.2010.05.006.

Bollschweiler M, Stoffel M, Ehmisch M and Monbaron M, 2007. Reconstructing spatio-temporal patterns of debris-flow activity using dendrogeomorphological methods. Geomorphology 87(4): 337-351, DOI 10.1016/j.geomorph.2006.10.002.

Bollschweiler M, Stoffel M and Schneuwly DM, 2008. Dynamics in debris-flow activity on a forested cone - A case study using differ- ent dendroecological approaches. Catena 72(1): 67-78, DOI 10.1016/j.catena.2007.04.004.

Bollschweiler M, Stoffel M, Vázquez-Selem L and Palacios D, 2010. Tree-ring reconstruction of past lahar activity at Popocatépetl volcano, México. The Holocene 20(2): 265-274, DOI $10.1177 / 0959683609350394$.

Bollschweiler M,Stoffel M and Schläppy R, 2011. Debris-flood reconstruction in a pre-alpine catchment in Switzerland based on treering records of coniferous and broadleaved trees. Geografiska Annaler Series $A$ 93(1): 1-15, DOI 10.1111/j.14680459.2011.00001.x.

Braam RR, Weiss EJJ and Burrough PA, 1987. Spatial and temporal analysis of mass movement using dendrochronology. Catena 14(6): 573-584, DOI 10.1016/0341-8162(87)90007-5.

Butler DR and Malanson GP, 1985. A History of High-Magnitude Snow Avalanches, Southern Glacier National Park, Montana, U.S.A. Mountain Research and Development 5(2): 175-182.

Butler DR and Sawyer CF, 2008. Dendrogeomorphology and highmagnitude snow avalanches: a review and case study. Natural Hazards and Earth System Sciences 8(2): 303-309, DOI 10.5194/nhess-8-303-2008.

Carrara PE and O'Neill JM, 2003. Tree-ring dated landslide movements and their relationship to seismic events in southwestern Montana, USA. Quaternary Research 59(1): 25-35, DOI 10.1016/S00335894(02)00010-8.

Casteller A, Stöckli V, Villalba R and Mayer AC, 2007. An Evaluation of Dendroecological Indicators of Snow Avalanches in the Swiss Alps. Arctic, Antarctic and Alpine Research 39(2): 218-228, DOI 10.1657/1523-0430(2007)39[218:AEODIO]2.0.CO;2.

Casteller A, Villalba R, Araneo D and Stöckli V, 2011. Reconstructing temporal patterns of snow avalanches at Lago del Desierto, southern Patagonian Andes. Cold Regions Science and Technology 67(1-2): 68-78, DOI 10.1016/j.coldregions.2011.02.001.

Casteller A, Villaba R, Mayer A and Stöckli V, 2009. Reconstrucción espacial y temporal de la ocurrencia de avalanchas de nieve en los Andes patagónicos utilizando técnicas dendrocronológicas. Revista chilena de historia natural 82(2): 245-264. (in Spanish) 
Cook ER and Kairiukstis LA, 1990. Methods of Dendrochronology. Applications in the Environmental Sciences. Kluwer, Netherlands. $394 \mathrm{pp}$.

Corominas J and Moya J, 1999. Reconstructing recent landslide activity in relation to rainfall in Llobregat river basin, Eastern Pyrenees, Spain. Geomorphology 30(1-2): 79-93, DOI 10.1016/S0169555X(99)00046-X.

Corominas J and Moya J, 2010. Contribution of dendrochronology to the determination of magnitude-frequency relationships for landslides. Geomorphology 124(3-4): 137-149, DOI 10.1016/j.geomorph.2010.09.001.

Corona Ch, Lopez Saez J, Stoffel M, Bonnefoy M, Richard D, Astrade L and Berger F, 2012. How much of the real avalanche activity can be captured with tree rings? An evaluation of classic dendrogeomorphic approaches and comparison with historical archives. Cold Regions Science and Technology 74-75: 31-42, DOI 10.1016/j.coldregions.2012.01.003.

Corona Ch, Rovéra G, Lopez Saez J, Stoffel M and Parfettini P, 2010. Spatio-temporal reconstruction of snow avalanche activity using tree rings: Pierres Jean Jeanne avalanche talus, Massif de l'Oisans, France. Catena 83(2-3): 107-118, DOI 10.1016/j.catena.2010.08.004

Decaulne A, Eggertsson Ó and Sæmundsson P, 2012. A first dendrogeomorphologic approach of snow avalanche magnitude-frequency in Northern Iceland. Geomorphology 167-168: 35-44, DOI 10.1016/j.geomorph.2011.11.017.

Decaulne A and Sæmundsson P, 2008. Dendrogeomorphology as a tool to unravel snow-avalanche activity: Preliminary results from the Fnjóskadalur test site, Northern Iceland. Norwegian Journal of Geography 62(2): 55-65, DOI 10.1080/00291950802094742.

Dorren LKA and Berger F, 2006. Stem breakage of trees and energy dissipation during rockfall impacts. Tree Physiology 26(1): 63-71, DOI 10.1093/treephys/26.1.63.

Dubé S, Filion L and Hétu B, 2004. Tree-Ring Reconstruction of HighMagnitude Snow Avalanches in the Northern Gaspé Peninsula, Québec, Canada. Arctic, Antarctic and Alpine Research 36(4): 555-564, DOI $10.1657 / 1523-$ 0430(2004)036[0555:TROHSA]2.0.CO;2.

Duncker P and Spiecker H, 2008. Cross-sectional compression wood distribution and its relation to eccentric radial growth in Picea abies [L.] Karst. Dendrochronologia 26(3): 195-202, DOI 10.1016/j.dendro.2008.06.004.

Fantucci R and Sorriso-Valvo M, 1999. Dendrogeomorphological analysis of a slope near Lago, Calabria (Italy). Geomorphology 30(1-2): 165-174, DOI 10.1016/S0169-555X(99)00052-5.

Friedman JM, Vincent KR and Shafroth PB, 2005. Dating floodplain sediments using tree-ring response to burial. Earth Surface Processes and Landforms 30(9): 1077-1091, DOI 10.1002/esp.1263.

Garavaglia V and Pelfini M, 2011. The role of border areas for dendrochronological investigations on catastrophic snow avalanches: A case study from the Italian Alps. Catena 87(2): 209-215, DOI 10.1016/j.catena.2011.06.006.

Gärtner H, 2007a. Glacial landforms, tree rings - Dendrogeomorphology. In: Elias PP, ed, Encyclopedia of Quaternary Science. University of London. 979-988.

Gärtner H, 2007b. Tree roots - Methodological review and new development in dating and quantifying erosive processes. Geomorphology 86(3-4): 243-251, DOI 10.1016/j.geomorph.2006.09.001.

Gärtner H and Heinrich I, 2009. The Formation of Traumatic Rows of Resin Ducts in Larix decidua and Picea abies (Pinaceae) as a Result of Wounding Experiments in the Dormant Season. IAWA Journal 30(2): 199-215.

Gärtner H and Nievergelt D, 2010. The core-microtome: A new tool for surface preparation on cores and time series analysis of varying cell parameters. Dendrochronologia 28(2): 85-92, DOI 10.1016/j.dendro.2009.09.002.

Germain D, Hétu B and Filion L, 2010. Tree-ring Based Reconstruction of Past Snow Avalanche Events and Risk Assessment in Northern Gaspé Peninsula (Québec, Canada). In: Stoffel M, Bollschweiler M, Butler DR and Luckman BH, eds, Tree Rings and Natural
Hazards. Advances in Global Change Research 41. Springer, Dordrecht Heidelberg London New York: 51-73.

Gers E, Florin N, Gärtner H, Glade T, Dikau R and Schweingruber FH, 2001. Application of shrubs for dendrogeomorphological analysis to reconstruct spatial and temporal landslide movement patterns. A preliminary study. Zeitschrift für Geomorphologie N.F. Suppl. 125: $163-175$.

Grau HR, Easdale TA and Paolini L, 2003. Subtropical dendroecology dating disturbances and forest dynamics in northwestern Argentina montane ecosystems. Forest Ecology and Management 177(1-3): 131-143, DOI 10.1016/S0378-1127(02)00316-X.

Grissino-Mayer H, 2001. Evaluating crossdating accuracy: A manual and tutorial for the computer program COFECHA. Tree-Ring Research 57(2): 205-221.

Guida D, Pelfini M and Santilli M, 2008. Geomorphological and dendrochronological analyses of a complex landslide in the southern Apennines. Geografiska Annaler 90A(3): 211-226.

Hebertson EG and Jenkins MJ, 2003. Historic climate factors associated with major avalanche years on the Wasatch Plateau, Utah. Cold Regions Science and Technology 37(3): 315-332, DOI 10.1016/S0165-232X(03)00073-9.

Heinrich I and Gärtner H, 2008. Variations in tension wood of two broad-leaved tree species in response to different mechanical treatments: implications for dendrochronology and mass movement studies. International Journal of Plant Sciences 169(7): 928936, DOI 10.1086/589695.

Hitz OM, Gärtner H, Heinrich I and Monbaron M, 2008. Wood anatomical changes in roots of European ash (Fraxinus excelsior L.) after exposure. Dendrochronologia 25(3): 145-152, DOI 10.1016/j.dendro.2007.03.005

Hupp CR, 1984. Dendrogeomorphic evidence of debris flow frequency and magnitude at Mount Shasta, California. Environmental Geology 6(2): 121-128, DOI 10.1007/BF02509918.

Kaczka RJ, Deslauriers A and Morin H, 2010. High-Precision Dating of Debris-Flow Events Within Growing Season. In: Stoffel M, Bollschweiler M, Butler DR and Luckman BH, eds, Tree Rings and Natural Hazards. Advances in Global Change Research 41. Springer, Dordrecht Heidelberg London New York: 227-229.

Kent M, Owen NW, Dale P, Newnham RM and Giles TM, 2001. Studies of vegetation burial: a focus for biogeography and biogeomorphology? Progress in Physical Geography 25(4): 455-482, DOI 10.1177/030913330102500401.

Kogelnik-Mayer B, Stoffel M, Schneuwly-Bollschweiler M, Hübl J and Rudolf-Mikau F, 2011. Possibilities and Limitations of Dendrogeomorphic Time-Series Reconstructions on Sites Influenced by Debris Flows and Frequent Snow Avalanche Activity. Arctic, Antarctic and Alpine Research 43(4): 649-658, DOI 10.1657/1938-424643.4.659.

Köse N, Aydin A, Akkemik Ü, Yurtseven H and Güner T, 2010. Using tree-ring signals and numerical model to identify the snow avalanche tracks in Kastamonu, Turkey. Natural Hazards 54(2): 435449, DOI 10.1007/s11069-009-9477-x.

Kukal Z and Pošmourný K, 2005. Př́rodní katastrofy a rizika. Ministerstvo životního prostředí České republiky. Praha. 51 pp. (in Czech)

Lang A, Moya J, Corominas J, Schrott L and Dikau R, 1999.Classic and new dating methods for assessing the temporal occurrence of mass movements. Geomorphology 30(1-2): 33-52, DOI 10.1016/S0169$555 \mathrm{X}(99) 00043-4$.

Laxton SC and Smith DJ, 2009. Dendrochronological reconstruction of snow avalanche activity in the Lahul Himalaya, Northern India. Natural Hazards 49(3): 459-467, DOI 10.1007/s11069-008-92885.

Lepš J and Šmilauer P, 2003. Multivariate analysis of ecological data using CANOCO. CUP, Cambridge, 292 pp.

Lopez Saez J, Corona Ch, Stoffel M, Astrade L, Berger F and Malet J-P, 2012a. Dendrogeomorphic reconstruction of past landslide reactivation with seasonal precision: the Bois Noir landslide, southeast French Alps. Landslides 9(2): 189-203, DOI 10.1007/s10346-0110284-6.

Lopez Saez J, Corona Ch, Stoffel M and Berger F, 2012b. Highresolution fingerprints of past landsliding and spatially explicit, 
probabilistic assessment of future reactivations: Aiguettes landslide, Southeastern French Alps. Tectonophysics in press, DOI: 10.1016/j.tecto.2012.04.020.

Lopez Saez J, Corona Ch, Stoffel M, Scoeneich P and Berger F, 2012c. Probability maps of landslide reactivation derived from tree-ring records: Pra Bellon landslide, southern French Alps. Geomorphology 138(1): 189-202, DOI 10.1016/j.geomorph.2011.08.034.

Malik I and Matyja M, 2008. Bank erosion history of a mountain stream determined by means of anatomical changes in exposed tree roots over last 100 years (Bílá Opava River - Czech republic). Geomorphology 98(1-2): 126-142, DOI 10.1016/j.geomorph.2007.02.030.

Malik I and Owczarek P, 2009. Dendrochronological records of debris flow and avalanche activity in a mid-mountain forest zone (Eastern Sudetes - Central Europe). Geochronometria 34: 57-66, DOI 10.2478/v10003-009-0011-7.

May $\mathrm{ChL}$ and Gresswell RE, 2004. Spatial and temporal patterns of debris-flow deposition in the Oregon Coast Range, USA. Geomorphology 57(3-4): 135-149, DOI 10.1016/S0169-555X(03)00086-2.

Mayer B, Stoffel M, Bollschweiler M, Hübl J and Rudolf-Miklau F, 2010. Frequency and spread of debris floods on fans: A dendrogeomorphic case study from a dolomite catchment in the Austrian Alps. Geomorphology 118(1-2): 199-206, DOI 10.1016/j.geomorph.2009.12.019.

Migoń P, Pánek T, Malik I, Hrádecký J, Owczarek P and Šilhán K., 2010. Complex landslide terrain in the Kamienne Mountains, Middle Sudetes, SW Poland. Geomorphology 124(3-4): 200-214, DOI 10.1016/j.geomorph.2010.09.024.

Moya J, Corominas J, Pérez Arcas J and Baeza C, 2010. Tree-ring based assessment of rockfall frequency on talus slopes at Solàd'Andorra, Eastern Pyrenees. Geomorphology 118(3-4): 393-408, DOI 10.1016/j.geomorph.2010.02.007.

Mundo IA, Barrera MD and Roig FA, 2007. Testing the utility of Nothofagus pumilio for dating a snow avalanche in Tierra del Fuego, Argentina. Dendrochronologia 25(1): 19-28, DOI 10.1016/j.dendro.2007.01.001.

Muntán E, García C, Oller P, Martí G, García A and Gutiérrez E, 2009. Reconstructing snow avalanches in the Southeastern Pyrennes. Natural Hazards and Earth System Science 9(5): 1599-1612, DOI 10.5194/nhess-9-1599-2009.

Owczarek P, 2010. Dendrochronological dating of geomorphic processes in the High Arctic. Landform Analysis. 14: 45-56.

Pallardy SG and Kozlowski TT, 2008. Physiology of woody plants. 3th edition. Academic Press - Elsevier. Oxford, 454 pp.

Paolini L, Villalba R and Ricardo Grau H, 2005. Precipitation variability and landslide occurrence in a subtropical ecosystem of NW Argentina. Dendrochronologia 22(3): 175-180, DOI 10.1016/j.dendro.2005.06.001.

Perret S, Stoffel M and Kienholz H, 2006. Spatial and temporal rockfall activity in a forest stand in the Swiss Prealps - A dendorgeomorphological case study. Geomorphology 74(1-4): 219-231, DOI 10.1016/j.geomorph.2005.08.009.

Procter E, Bollschweiler M, Stoffel M and Neumann M, 2011. A regional reconstruction of debris-flow activity in the Northern Calcareous Alps, Austria. Geomorphology 132(1-2): 41-50, DOI 10.1016/j.geomorph.2011.04.035.

Reardon BA, Pederson GT, Caruso CJ and Fagre DB, 2008. Spatial Reconstructions and Comparisons of Historic Snow Avalanche Frequency and Extent Using Tree Rings in Glacier National Park, Montana, U.S.A. Arctic, Antarctic and Alpine Research 40(1): 148-160, DOI 10.1657/1523-0430(06-069)[REARDON]2.0.CO;2.

Rossi S, Deslauriers A, Anfodillo T, Morin H, Saracino A, Motta R and Borghetti M, 2006. Conifers in cold environments synchronize maximum growth rate of tree-ring formation with day length. New Phytologist $\quad 170(2): \quad 301-310, \quad$ DOI $\quad 10.1111 / j .1469-$ 8137.2006.01660.x.

Santilli M and Pelfini M, 2002. Dendrogeomorphology and dating of debris flows in the Valle del Gallo, Central Alps, Italy. Dendrochronologia 20(3): 269-284, DOI 10.1078/1125-7865-00020.

Pelfini M and Santilli M, 2008. Frequency of debris flows and their relation with precipitation: A case study in the Central Alps, Italy.
Geomorphology 101(4):

$721-730$

DOI

10.1016/j.geomorph.2008.04.002

Shroder JF, 1978. Dendrogeomorphological Analysis of Mass Movement on Table Cliffs Plateau, Utah. QuaternaryResearch 9(2): 168-185, DOI 10.1016/0033-5894(78)90065-0.

Schneuwly DM and Stoffel M, 2008a. Spatial analysis of rockfall activity, bounce heights and geomorphic changes over the last 50 years - A case study using dendrogeomorphology. Geomorphology 102(3-4): 522-531, DOI 10.1016/j.geomorph.2008.05.043.

Schneuwly DM and Stoffel M, 2008b. Tree-ring based reconstruction of the seasonal timing, major events and origin of rockfall on a casestudy slope in the Swiss Alps. Natural Hazards Earth System Sciences 8(2): 203-211, DOI 10.5194/nhess-8-203-2008.

Schneuwly DM, Stoffel M and Bollschweiller M, 2009. Formation and spread of callus tissue and tangential rows of resin ducts in Larix decidua and Picea abies following rockfall impacts. Tree Physiology 29(2): 281-289, DOI 10.1093/treephys/tpn026.

Schweingruber FH, 1996. Tree rings and Enviroment. Dendroecology.Biermersdorf, Swiss Federal Institute for Forest, Snow and Landscape Research. Berne, Stuttgart, Vienna, Haupt, 609 pp.

Schweingruber FH, 2007. Wood Structure and Environment. Springer. Verlag Berlin Heidelberg New York, 279 pp.

Sorg A, Bugmann H, Bollschweiler M and Stoffel M, 2010. Debris-flow activity along a torrent in the Swiss Alps: Minimum frequency of events and implications for forest dynamics. Dendrochronologia 28(4): 215-223, DOI 10.1016/j.dendro.2009.11.002.

Stefanini MC, 2004.Spatio-temporal analysis of a complex landslide in the Northern Apennines (Italy) by means of dendrochronology. Geomorphology 63(3-4): 191-202,

DOI 10.1016/j.geomorph.2004.04.003.

Stoffel M, 2008. Dating past geomorphic processes with tangential rows of traumatic resin ducts. Dendrochronologia 26(1): 53-60, DOI 10.1016/j.dendro.2007.06.002.

Stoffel M and Bollschweiler M, 2008.Tree-ring analysis in natural hazards research - an overview. Natural Hazards and Earth System Sciences 8(2): 187-202, DOI 10.5194/nhess-8-187-2008.

Stoffel M and Bollschweiler M, 2009a. What Tree Rings Can Tell About Earth-Surface Processes: Teaching the Principles of Dendrogeomorphology. Geography Compass 3(3): 1013-1037, DOI 10.1111/j.1749-8198.2009.00223.x.

Stoffel M and Bollschweiler M, 2009b. Tree-ring reconstruction of past debris flows based on a small number of samples - possibilities and limitations. Landslides 6(3): 225-230, DOI 10.1007/s10346009-0165-4.

Stoffel M, Bollschweiler M and Hasler G, 2006. Differentiating past events on a cone influenced by debris-flow and snow avalanche activity - a dendrogeomorphological approach. Earth Surface Processes and Landforms 31(11): 1424-1437, DOI 10.1002/esp.1363.

Stoffel M, Bollschweiler M, Vázquez-Selem L, Franco-Ramos O and Palacios D, 2011. Dendrogeomorphic dating of rockfalls on low - latitude, high - elevation slopes: Rodadero, Iztaccíhuatl volcano, Mexico. Earth Surface Processes and Landforms 36(9): 1209-1217, DOI 10.1002/esp.2146.

Stoffel M and Hitz OM, 2008. Rockfall and snow avalanche impacts leave different anatomical signatures in tree rings of juvenile Larix decidua. Tree Physiology 28: 1713-1720, DOI 10.1093/treephys/28.8.1713.

Stoffel M and Perret S, 2006. Reconstructing past rockfall activity with tree rings: Some methodological considerations. Dendrochronologia 24(1): 1-15, DOI 10.1016/j.dendro.2006.04.001.

Stoffel M, Lièvre I, Conus D, Grichting MA, Raetzo H, Gärtner HW and Monbaron M, 2005a. 400 Years of Debris-Flow Activity and Triggering Weather Conditions: Ritigraben, Valais, Switzerland. Arctic, Antarctic, and Alpine Research. 37(3): 387-395, DOI 10.1657/1523-0430(2005)037[0387:YODAAT]2.0.CO;2.

Stoffel M, Schneuwly D, Bollschweiler M, Liévre I, Delaloye R, Myint $\mathrm{M}$ and Monbaron M, 2005b. Analyzing rockfall activity (16002002) in a protection forest - a case study using dendrogeomorphology. Geomorphology 68(3-4): 224-241, DOI 10.1016/j.geomorph.2004.11.017. 
Stoffel M, Liévre I, Monbaron M and Perret S, 2005c. Seasonal timing of rockfall activity on a forested slope at Täschgufer (Swiss Alps) - a dendrochronological approach. Zeitschrift für Geomorphologie N.F. 49(1): 89-106.

Strunk H, 1997. Dating of geomorphological processes using dendrogeomorphological methods. CATENA 31(1-2): 137-151, DOI 10.1016/S0341-8162(97)00031-3.

Szymczak S, Bollschweiler M,Stoffel M and Dikau R, 2010. Debrisflow activity and snow avalanches in a steep watershed of the Valais Alps (Switzerland). Dendrogeomorphic event reconstruction and identification of triggers. Geomorphology 116(1-2): 107-114, DOI 10.1016/j.geomorph.2009.10.012.

Šilhán K, 2010a. Dendrogeomorphology of spatio-temporal activity of rockfall in the Flysch Carpathians: a case study on the western slope of Mt. Smrk (Moravskoslezské Beskydy Mts, Czech republic). Moravian Geographical Reports 18: 33-42.

Šilhán K, 2010b. Dendrochronologické datování blokovobahenních proudů (příkladová studie Slavíč; Moravskoslezské Beskydy). In: Geologické výzkumy na Moravě a ve Slezsku v roce 2010. Brno. 92-95.(in Czech)

Šilhán K, 2011. Prostorové aspekty aktivity skalního řícení (dendrogeomorfologická studie v Moravskoslezských Beskydech). Zprávy o geologických výzkumech v roce 2010. 83-86. (in Czech)

Šilhán K and Pánek T, 2008.Historická chronologie blokovobahenních proudů v Moravskoslezských Beskydech. Geomorphologia Slovaca et Bohemica. 8(1): 82-94.(in Czech)

Ter Braak CJF and Šmilauer P, 1998. CANOCO Reference Manual and User's Guide to Canoco for Windows. Software for Canonical Community Ordination (version 4). Centre for Biometry, Wageningen, $112 \mathrm{pp}$.
Vandekerckhove L, Muys B, Poesen J, De Weerdt B and Coppé N, 2001. A method for dendrochronological assessment of mediumterm gully erosion rates. CATENA 45(2): 123-161, DOI 10.1016/S0341-8162(01)00142-4.

Van der Burght L, Stoffel M and Bigler Ch, 2012. Analysis and modelling of tree succession on a recent rockslide deposit. Plant Ecology 213(1): 35-46, DOI 10.1007/s11258-011-0004-2.

Van Den Eeckhaut M, Muys B, Van Loy K and Beeckman H, 2009. Evidence for repated re-activation of old landslide under forest. Earth Surface Processes and Landforms 34(3): 352-365, DOI 10.1002/esp.1727.

Varnes DJ, 1978. Slope movement types and processes. In: Schuster RL and Krizek RJ,eds, Landslides, analysis and control. Transportation Research Board Sp. Rep. No. 176, Nat. Acad. of Sciences, 1133 .

Voiculescu M and Ardelean F, 2012. Snow avalanche - disturbance of high mountain environment. Case study - the Doamney glacial valley, the Făgăraş massif - Southern Carpathians, Romanian Carpathians. Carpathian Journal of Earth and Environmental Sciences 7(1): 95-108

Wieczorek GF, Scott Eaton L, Yanosky TM, Turner EJ, 2006. Hurricane-induced landslide activity on an alluvial fan along Meadow Run, Shenandoah Valley, Virginia (eastern USA). Landslides 3(2): 95-106, DOI 10.1007/s10346-005-0029-5.

Wilkerson FD and Schmid GL, 2003. Debris flows in Glacier National Park, Montana: geomorphology and hazards. Geomorphology 55(1-4): 317-328, DOI 10.1016/S0169-555X(03)00147-8.

Yoshida K, Kikuchi S, Nakamura $F$ and Noda $M$, 1997.Dendrochronological analysis of debris flow disturbance on Rishiri Island. Geomorphology 20(1-2): 135-145, DOI 10.1016/S0169-555X(97)00010-X. 